University of Nebraska - Lincoln

DigitalCommons@University of Nebraska - Lincoln

\title{
Challenging Balance Between Productivity and Environmental Quality: Tillage Impacts
}

D. C. Reicosky

USDA-ARS, don.reicosky@ars.usda.gov

T. J. Sauer

USDA-ARS

J. L. Hatfield

USDA-ARS, jerry.hatfield@ars.usda.gov

Follow this and additional works at: https://digitalcommons.unl.edu/usdaarsfacpub

Reicosky, D. C.; Sauer, T. J.; and Hatfield, J. L., "Challenging Balance Between Productivity and Environmental Quality: Tillage Impacts" (2011). Publications from USDA-ARS / UNL Faculty. 1373. https://digitalcommons.unl.edu/usdaarsfacpub/1373

This Article is brought to you for free and open access by the U.S. Department of Agriculture: Agricultural Research Service, Lincoln, Nebraska at DigitalCommons@University of Nebraska - Lincoln. It has been accepted for inclusion in Publications from USDA-ARS / UNL Faculty by an authorized administrator of DigitalCommons@University of Nebraska - Lincoln. 


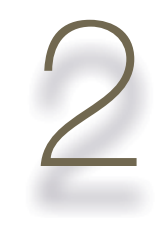

\section{Challenging Balance between Productivity and Environmental Quality: Tillage Impacts

\author{
D.C. Reicosky, T.J. Sauer, and J.L. Hatfield
}

$\mathrm{T}$ he increasing pressure to provide food security, enhance environmental quality, and address societal problems creates challenges for agriculture and requires we consider how to change our current systems to become more sustainable. Wiebe (2003) stated, "Not only is the contemporary food system inherently unsustainable, increasingly it is damaging the environment." There have been adverse effects in all parts of the world on soils, water, and biodiversity. Poor management of our agricultural systems has contributed to human-induced climate change, and, in turn, human-induced climate change threatens agricultural productivity. In many developed countries, access to quality food is taken for granted, and farmers and farm workers are poorly rewarded for acting as stewards of the Earth's land area used for agricultural production. There is little emphasis on the conservation ethic. More troubling, the environmental degradation caused by intensive agriculture will likely worsen as the global population grows to eight or ten billion in the next three decades.

Modern agriculture is no longer approached as a single issue and is a business that includes far more than just production of food. We have to learn how to pay farmers to not only produce food, animal feed, fiber, and biofuel, but to value the environmental services they impact during crop production. We must consider the environmental issues of biodiversity and water, the economic issues of marketing and trade, and the social concerns of gender and culture. All of this must be done in an economically, environmentally, and socially sustainable manner. We need a fundamental reevaluation of agricultural knowledge, science, and technology transfer to achieve a sustainable global food system. Challenges include giving farmers better access to knowledge, technology, and credit and bringing the necessary information and infrastructure to rural areas.

Much of the environmental damage from agriculture is directly related to the intensive tillage methods used in present-day agricultural production systems. The environmental damage takes a number of forms: erosion and salinization of soils, deforestation as more land is brought into cultivation, fertilizer runoff that ultimately creates enormous "dead zones" around the mouths of many rivers, loss of biodiversity, fresh water scarcity, and agrochemical pollution of water and soil (Lal et al., 2007).

D.C. Reicosky, USDA-ARS, North Central Soil Conservation Research Lab, 803 lowa Ave., Morris, MN 56267 (don.reicosky@ars.usda.gov); T.J. Sauer and J.L. Hatfield, USDA-ARS National Laboratory for Agriculture and the Environment, 2110 University Boulevard, Ames, IA 50011. The USDA is an equal opportunity provider and employer.

doi:10.2136/2011soilmanagement.c2

Copyright $\odot$ 2011. American Society of Agronomy and Soil Science Society of America, 5585 Guilford Road, Madison, WI 53711, USA. Soil Management: Building a Stable Base for Agriculture. Jerry L. Hatfield and Thomas J. Sauer (ed.) 
In short, we in developed countries create unprecedented abundance while ignoring the long-term consequences of our actions. This is reminiscent of previous agricultural societiesthe Greeks, Babylonians, and Romans-who all destroyed soil and habitat in their efforts to feed growing urban populations and collapsed as a result (Lowdermilk, 1953; Gebregziabher et al., 2006; Lal et al., 2007). Historical lessons from impacts of intensive agriculture and plow tillage provide modern civilization learning opportunities that can lead to a brighter future. Hopefully, we can quickly learn and act to avoid repeating history.

\section{Objective}

Agriculture uses natural resources-sun, soil, water, and air-to produce food. We in developed countries still have a poor understanding of the properties and conditions of these critical resources. Intensive agriculture can lead to deterioration in the quality of these natural resources and their ability to support food production for an expanding population. The consequences of intensive agriculture on environmental quality require reevaluation and an enhanced educational effort to bring together a better understanding of the unintended human impact on our food production systems (Tinker, 1998; Wiebe, 2003). The contemporary buzzword "sustainable development" has become overworked and needs to be related to productivity and environmental quality (Du Pisani, 2006). The

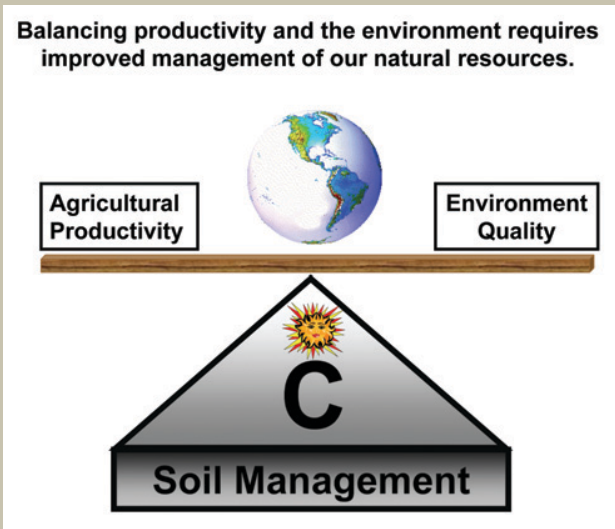

Fig. 2|1. Our world rests on balancing agricultural productivity and environmental quality through improved soil management and carbon cycling. objective of this chapter is to identify key issues that need to be addressed to maintain agricultural production for the expanding population with minimal impact on environmental quality by addressing agricultural, social, economic, and political issues as they interact to provide a quality of life acceptable to all. Emphasis will be placed on the importance of soil management, as illustrated in Fig. 2l1, particularly the unintended consequences of tillage, as the controlling factor in maintaining this delicate balance between agricultural productivity and environmental quality (Lal, 1998; Grandy et al., 2006; Robertson and Swinton, 2005; Sanchez et al., 2004; Sandor and Eash, 1995; Troeh et al., 1999).

\section{Global Population Growth and Land Available for Food Production}

One way to increase food production is to increase the amount of land devoted to agricultural production. Agriculture has a finite amount of land suitable, with today's technology, to support the ever-increasing global population and the accompanying required increase in the capacity of food production systems. About 71\% of the Earth's surface area is covered by oceans, and 29\% (148.9 million $\mathrm{km}^{2}$ ) is land area (Weast, 1981). Icefree lands include desert and wastelands, forests and savannas, pasture and rangeland, swamps, bogs and lakes, and urban areas (FAOSTAT, 2009; Weast, 1968, 1981). As of 2006, about 37\% of Earth's land area was used for agriculture. About one-third of this area, or 11\% of Earth's total land ( 163 million ha), is used for arable crops. The balance, roughly $26 \%$ of Earth's land area, is pastureland, which includes cultivated or wild forage crops for animals and open land used for grazing (FAOSTAT, 2009).

Population growth is expected to increase, and the world population is projected to reach ten billion by 2050, which decreases the per capita arable land. The estimated global population in 2008 was 6.707 billion people and is presently expanding at the rate of $\sim 1.2 \%$ per year (U.S. Census Bureau, 2007). These numbers indicate that annual individual food and living requirement must be grown on 
$\sim 0.21$ ha of arable land. This is the same area as a square lawn area $46 \mathrm{~m}$ on each side. If we include the area of permanent crops and permanent pastures as an area to produce food and living space, then each individual has $\sim 0.74$ ha. These estimates are similar to those of Ramankutty et al. (2002), who stated, "the cropland base diminished from $\sim 0.75$ ha person $^{-1}$ in 1900 to $\sim 0.35$ ha person ${ }^{-1}$ in 1990 . This loss of croplands was not globally uniform, and more than half the world's population, living in developing nations, lost nearly two-thirds of their per capita cropland base." More intensive agricultural production will have to meet the increasing food demands for this increasing population, especially because of an increasing demand for land area to be used for biofuels. Thus, the long-term soil degradation as a result of intensive plow tillage must be addressed, and heeding its implications for long-term food security must significantly influence our agricultural management practices to protect soil quality for our expanding population. Overall, the global food production system is increasingly vulnerable to regional disruptions because of our increasing reliance on expensive technological options related to fossil fuels to increase agricultural production.

The FAO (FAOSTAT, 2009) categories of agricultural land (total of 4,967,579,500 ha) may not be precise quantitatively because they do not reflect land that has gone out of production or other land that may be potentially used for future production. The potential for increased production on good-quality cropland is considerably more limited; however, there does appear to be some potential to bring new land under cultivation, even though it may be a relatively small amount. Bringing new land under production must be balanced by losses of land area used for production. As the population grows and urban areas expand, some farmland is paved over. The impact of urban sprawl is obvious in many developed countries, especially in the United States. On a worldwide basis this sprawl takes up only 3\% of the land area, but it will eventually have an effect on global agriculture (Heimlich and Anderson, 2001; Gardner, 1996; Buringh, 1989).

The global climate change attributed to agriculture may result in some redistribution of agricultural production more favorable to the crop plants. The primary concern of many experts is that land currently in production, may eventually be degraded by soil loss or contamination to such a degree that can be no longer used to grow crops (Larson et al., 1983; Lal, 1989, 1998; Pimentel et al., 1995; Lal et al., 1998). Gardner (1996) stated, "While the world's major grain producers have over expanded into marginal land in recent years, damaging large areas of land in the process, they now are pulling back the land that can be cultivated with a resulting loss in grain production." However, these definitions and estimated areas indicate the relatively small land area per capita available for food production to cope with the expanding global population.

From the global soil map and soil climate GIS information, Beinroth et al. (1994) stated that "about $29.45 \%$ of the Earth's icefree land surface is too dry for sustainable human habitation). Advanced water and energy supply and irrigation techniques have enabled some use of these arid lands. About $(15.46 \%)$ of the land is the cold tundra zone, which are not easily amenable to normal agriculture." Eswaran et al. (1997) noted that "there are other constraints, which prevent the use of soils for agriculture. Saline and alkaline soils, for example, occupy $2.4 \%$ of the land surface, and soil acidity affects $14.1 \%$ of the total land. There are sloping lands, sandy soils, soils with low water and/or nutrient-holding capacity, soils with high organic matter (peats), etc. Some limitations are considered permanent or cannot be corrected by low to medium-level inputs."

Smil (1987) stated that "a country with less than 0.07 ha of arable land per person cannot feed its population in the absence of very intensive agriculture. This is a population supporting capacity of about 14 persons per ha of land, which itself is an unrealistically high number. The fossil energy inputs required to produce sufficient food at this level would be excessively high for any meaningful output. With countries that have per capita land area numerically close to 0.07 ha; this does not imply that their agriculture production is designed to support 14 or more persons. The concern is the 0.07 ha estimate is now widely used by United Nations organizations as an optimistic reference for evaluating agricultural land's carrying capacity." 


\section{Effect of Climate Change on Agriculture}

The IPCC report (IPCC, 2007) stated, "Global environmental change concerns us all." Scientists have assembled the evidence for climate change and emphasized its anthropogenic causes. In a remarkably short time, scientists have concluded that warming of the climate system is "unequivocal" and that there is a "very high confidence that the globally averaged net effect of human negativity since 1750 has been one of warming." The much greater problem for farmers is destabilization of weather patterns. We face not just a warmer climate, but climate chaos: droughts, floods, and stronger storms in general (hurricanes, cyclones, tornadoes, hail storms)-in short, unpredictable weather of all kinds. Farmers depend on relatively consistent seasonal patterns of rain and sun, cold and heat; a climate shift can spell the end of farmers' ability to grow a crop in a given region, and a single storm can destroy an entire year's production. Eswaran et al. (1997) concluded, "Environmental degradation, water shortages, salinization, soil erosion, pests, disease, and desertification all pose serious threats to our food supply, and are made worse by climate change. But many of the conventional ways used to overcome these environmental problems further increase the consumption of finite oil and gas reserves and environmental degradation as we attempt to maintain agricultural productivity for the expanding population." Science may lay out the possibilities but cannot affect the solutions that require social and economic interaction and policy implementation.

Global warming can affect crop yields in a variety of ways, both positively and negatively (Rosenzweig and Hillel, 1995). The increase in atmospheric carbon dioxide concentration increases the efficiency of photosynthesis and thereby enhances plant growth and increases water-use efficiency. The higher temperatures associated with global warming will increase the length of the growing season, and thus, agricultural production may become feasible in areas presently too cold. The increased temperatures may cause plants to mature faster, but any yield loss may be offset using double cropping techniques. Another concern is that pests and diseases often thrive in higher temperature conditions and may contribute to lower yields. Using models, Rosenzweig et al. (1993) estimated that if temperatures increased by $2^{\circ} \mathrm{C}$, then maize and rice yields will increase about $8 \%$. One major negative is the frequency of extreme meteorological events such as unseasonable frosts, hurricanes, tornadoes, heavy rainstorms, and droughts, which can all disrupt crop production and cause lower yields.

Another concern is that global warming may cause agricultural production to shift from one geographical area to another. There may be production time lost as we adapt to this shift in climate change, and another secure food source may be required during this transition stage. There are concerns that problems in establishing the institutional and infrastructure needed to move the food from the production area to the consuming areas can be considerable (Rosenzweig and Hillel, 1995). Rosenzweig and Hillel (1995) noted, "While the overall, global impact of climate change on agriculture production may be small, regional_food deficits may increase, due to problems of distributing and marketing food to specific regions and groups of people."

A recent comprehensive report covering this subject is one of a series of products from the U.S. Climate Change Science Program (CCSP, 2008), with special emphasis on agriculture covered by Hatfield et al. (2008). This report builds on extensive scientific literature and a series of recent assessments of the historical and potential impacts of climate change and climate variability on managed and unmanaged ecosystems and their constituent biota and processes. The general time horizon for this report is from the recent past through the period 20302050, although longer-term results out to 2100 are also considered. Assessment of the effects of climate change on U.S. agriculture, land resources, water resources, and biodiversity are provided. These insights are mainly focusing on effects of climate on cropping systems, pasture and grazing lands, and animal management. The report discusses the nation's ability to identify, observe, and monitor the stresses that influence agriculture, land resources, water resources, and biodiversity, and evaluates the relative importance of these stresses and how they are likely to change in the future.

Briefly, the CCSP (2008) report summarizes the effects of climate change on U.S. land and 
water resources, agriculture, and biodiversity and provides the following conclusions:

1. Climate changes-temperature increases, increasing $\mathrm{CO}_{2}$ levels, and altered patterns of precipitation-are already affecting U.S. water resources, agriculture, land resources, and biodiversity.

2. Climate change will continue to have significant effects on these resources over the next few decades and beyond.

3. Many other stresses and disturbances are also affecting these resources in the form of multiple environmental drivers (e.g., land use change, nitrogen (N) cycle changes, point and nonpointsource pollution, wildfires, invasive species) that are also changing.

4. Climate change impacts on ecosystems will affect the services that ecosystems provide, such as cleaning water and removing carbon (C) from the atmosphere, but we do not yet possess sufficient understanding to project the timing, magnitude, and consequences of many of these effects.

5. Existing monitoring systems, while useful for many purposes, are not optimized for detecting the impacts of climate change on ecosystems and natural resources.

Even under the most optimistic $\mathrm{CO}_{2}$ emission scenarios, important changes in sea level, regional and subregional temperatures, and precipitation patterns will have profound effects on both agricultural production and environmental quality (Smith et al., 2008). They state:

Management of water resources will become more challenging. Increased incidence of disturbances such as forest fires, insect outbreaks, severe storms, and drought will command public attention and place increasing demands on management resources. Ecosystems are likely to be pushed increasingly into alternate states with the possible breakdown of traditional species relationships, such as pollinator/plant and predator/prey interactions, adding additional stresses and potential for system failures. Some agricultural and forest systems may experience near-term productivity increases, but over the long term, many such systems are likely to experience overall decreases in productivity that could result in economic losses, diminished ecosystem services, and the need for new, and in many cases significant, changes to management regimes.

The CCSP report addressed the broad agricultural problems through consideration of cropping systems, pasture and grazing lands, and animal management (Hatfield et al., 2008). They state:

"The many U.S. crops and livestock varieties are grown in diverse climates, regions, and soils. No matter the region, however, weather and climate factors such as temperature, precipitation, $\mathrm{CO}_{2}$ concentrations, and water availability directly impact the health and well-being of plants, pasture, rangeland, and livestock which all translate to productivity. For any agricultural commodity, variation in yield between years is related to growing-season weather; weather also influences insects, disease, and weeds, which in turn affect agricultural production."

Hatfield et al. (2008) stated:

The primary conclusions for the agricultural sector were:

- With increased $\mathrm{CO}_{2}$ and temperature, the life cycle of grain and oilseed crops will likely progress more rapidly. But, as temperature rises, these crops will increasingly begin to experience failure, especially if climate variability increases and precipitation lessens or becomes more variable.

- The marketable yield of many horticultural crops-e.g., tomatoes, onions, fruits-is very likely to be more sensitive to climate change than grain and oilseed crops.

- Climate change is likely to lead to a northern migration of weeds. Many weeds respond more positively to increasing $\mathrm{CO}_{2}$ than most cash crops, particularly C3 "invasive" weeds. Recent research also suggests that glyphosate, the most widely used herbicide in the United States, loses its efficacy on weeds grown at the 
increased $\mathrm{CO}_{2}$ levels likely in the coming decades.

- Disease pressure on crops and domestic animals will likely increase with earlier springs and warmer winters, which will allow proliferation and higher survival rates of pathogens and parasites. Regional variation in warming and changes in rainfall will also affect spatial and temporal distribution of disease.

The importance of water in agricultural production cannot be overstated. While a very critical issue in balancing agricultural productivity and environmental quality, climate change impacts on water deficits are a critically important aspect of agricultural production (Postel, 1989). Agriculture's demand and use of water continues to expand to meet the food needs of our expanding population. On land, the amount and frequency of rainfall determine the success of crops, as well as the survival of natural and agricultural ecosystems. Precipitation varies by both season and geographic area, with large impacts on both agricultural productivity and environmental quality. As one result, highly specialized ecosystems have developed, from deserts to rain forests. In the event of global warming, regional rainfall patterns may shift. Similarly, the removal of forest cover for agricultural production may alter rainfall distribution because of reduced evaporation of water from plants. Changes in patterns of precipitation could have dramatic effects, positive or negative, on all life on Earth.

Irrigation has underpinned the advancement of human societies for several thousand years by enabling farmers to apply water when and where needed, turning many of the Earth's sunniest, warmest, and most fertile lands into important cropproduction regions (Postel, 1989). Today, farming accounts for some $70 \%$ of global water use. In recent years, however, forces have begun to slow irrigation's expansion and to raise questions about agriculture's heavy claim on the world's rivers, streams, and underground aquifers. As air temperatures rise and rainfall patterns shift with the onset of climate change, water supplies will increase in some areas and decrease in others. Whatever the outcome for particular regions, adjusting the global irrigation base to the changes in water availability will be costly. Moving rapidly to greater efficiency and equity in the use of water is the surest way to avert shortages and lessen irrigation's ecological toll. Stepped-up research into breeding strains of crops that are more salt tolerant and drought resistant would help prepare for a likely future of increased shortages and hotter, drier climates in some important food growing regions. The delicate balance between agricultural productivity and environmental quality rests on balancing the water budgets of many countries as much as slowing the rapidly growing populations (Postel, 1989).

\section{Environmental Issues: Resource Management versus Resource Conservation}

\section{Soil Quality and Soil Degradation}

Soil quality is the fundamental foundation of environmental quality. Soil quality is largely governed by soil organic matter (SOM) content, which is dynamic and responds effectively to changes in soil management, primarily tillage and $C$ input (Lal, 1987, 2003). Maintaining soil quality through carbon management can reduce problems of land degradation, decreasing soil fertility, and rapidly declining production levels that occur in large parts of the world needing the basic principles of good farming practice (Lal, 1989, 1995, 2003).

Soil quality is a way of expressing the potential productivity of the soil based on qualitative attributes. While there are many attributes of soil quality, the one that contributes the most to "good properties" of the soil is the carbon content. While a typical soil carbon content can have a range of up to $5 \%$ in mineral soils, the small amount of carbon is very critical for optimizing the soil physical, chemical, and biological properties. The overlapping interaction in the role of soil carbon and impacting soil properties is illustrated in Fig. 2/2. The critical role of soil carbon in maintaining these properties is also linked to agricultural global warming issues that may have contributed to the increase in atmospheric $\mathrm{CO}_{2}$ (Lal, 1995, 1999a, 2003, 2004).

There is a global and urgent need for restoring the quality of degraded soils. 
The urgency is highlighted by large areas of land degraded to some extent (Lal, 1987, 1989, 1998; Oldeman et al., 1991), and the need is underscored by the world's finite soil resources and high population pressure. The per capita arable land area is rapidly shrinking, especially in densely populated China and India, where arable land resources are limited and the soil degradation risks are alarmingly high. Critical strategies for soil restoration must be identified on the basis of the concepts of soil resilience. Soil resilience refers to the ability of soil to resist or recover from an anthropogenic or natural disturbance (Greenland and Szabolc, 1994; Lal, 1997). Soils differ in resilience depending on several inherent characteristics. Highly resilient soils have high buffering capacities and high rates of recovery or restoration. Fragile soils, in contrast, are unstable, cannot recover to the initial state, and may have lost some of their initial characteristics (Greenland and Szabolc, 1994). Soil resilience is closely linked to soil quality through soil carbon, because resilient soils have high soil quality and vice versa. Therefore, soil resilience can be assessed from the rate of change of soil quality with time (Lal, 1994).

Knowledge of soil resilience is essential to adopting appropriate restorative measures. The choice of restoration techniques depends on numerous factors, including the on-site and off-site impacts, socioeconomic issues of the farm household, and institutional support and policy issues. However, biophysical processes affecting soil quality decline are extremely important in the choice of technical measures. Equally or more important are the magnitudes of the past erosion and the current rate of soil erosion (Lal, 1987, 2003). The soil erosion must be controlled while alleviating the soil quality-related constraints caused by the past soil erosion. Because of the complexity of the problem and numerous interacting factors involved, it is appropriate to adopt an agroecosystem approach to soil quality restoration (Lal, 1989).

Contributing to a better understanding of tillage impacts on the environment, Warkentin (2008) defined soil tilth as the "condition" of a soil in relation to the habitat provided for seed germination and plant growth. Soil structure of surface horizons was perceived for many years as tilth of the seedbed and plowing or tillage to achieve it.
The early social and technical history of tilth was largely the history of how to plow and how to plow well (Lal et al., 2007). With the advent of soil science laboratories, the dominant concern soon became measurement of static properties expected to be related to tilth and stability of structure: aggregate-size distribution, soil bulk density to calculate porosity, grain-size distribution, shape and size of aggregates, and stability of aggregates (Mikha and Rice, 2004; Olchin et al., 2008; Shepherd et al., 2001; BlancoCanqui and Lal, 2004; Warkentin, 2008). The importance of organic matter and clay content in soil structure was generally recognized; however, all these soil properties were related to changes in soil caused by cultivation, and cultivation impacts on tilth and crop yield (Tisdall and Oades, 1982). Tisdall (1996) stated, "the concept of hierarchical arrangement of different aggregate sizes, and the bonds responsible for stability, drew attention to different void sizes and to the soil functions of each. The unique role of soil in ecosystems led to considering soil structure as defining the habitat for soil biological, physical, and chemical functions such as decomposition, water routing, etc. Structure is now a concept centered on voids, and the term soil architecture became more appropriate; the spaces and surfaces of the spaces were more important than the solids of walls and roof." Today's soil structure research is again productive in concepts and applications and encourages less intensive tillage (Jastrow et al., 1996; Six et al., 1998, 2002; Warkentin, 2008).

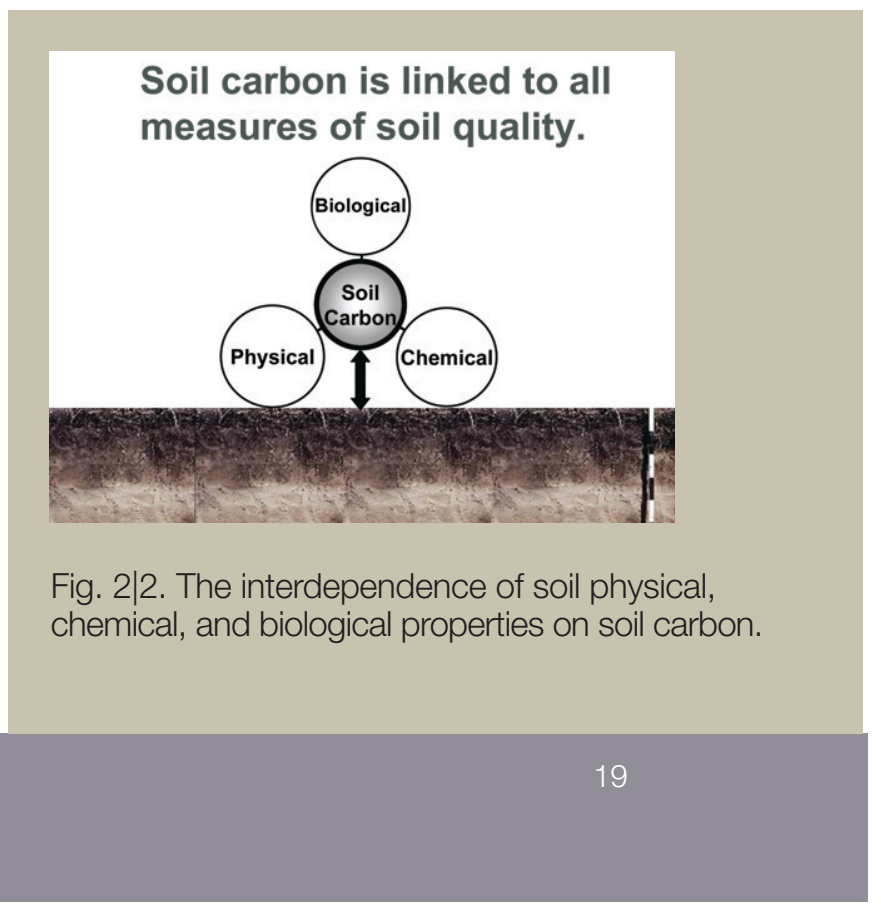




\section{Soil Erosion}

One of the most degrading forces acting on the soil is erosion. Soil erosion is caused by intensive agricultural production. Soil that is loosened by tillage is more easily transported by wind or water, increasing the rate of erosion. In annual production systems, the soil surface is left bare for months at a time, leaving a soil susceptible to erosion (Lal, 1987, 1995, 1998, 1999b, 2003).

Lal (1998) stated

Principal processes that lead to decline in crop yield due to erosion are: (1) reduction in effective rooting depth, (2) loss of plant nutrients and soil organic carbon (SOC), (3) loss of plant available water and available water-holding capacity (AWC), (4) loss of land area, and (5) damage to seedlings. There are also numerous indirect effects of accelerated soil erosion that are primarily due to the loss of resources during the season, for example, loss of fertilizer and agrichemicals, delayed sowing or re-sowing, supplemental irrigation required due to the loss of water runoff, additional machinery cost, etc. Other soil degradation processes, including compaction, acidification, toxic contamination, and salinization largely relate to specific regions in some countries.

On a global scale, the on-site effects of soil erosion are undermining the productivity of about $33 \%$ of the world's cropland (Pimentel, 1993; Pimentel et al., 1987, 1995; Brown and Young, 1990).

In the 1950s, when the Soil Conservation Service (now known as the Natural Resources Conservation Service) began defining "tolerable" rates of soil erosion from agricultural land, hardly any data on rates of soil formation were available. The agency thus determined the so-called soil loss tolerance values, or "T values," on the basis of what farmers could do to reduce erosion without "undue economic impact" using conventional farming equipment. These $\mathrm{T}$ values correspond to as much as $25.4 \mathrm{~mm}$ of erosion in $25 \mathrm{yr}$. But, recent research has shown the soil erosion rate to be far faster than the rate at which soil rebuilds (Montgomery, 2007; Heimsath et al., 1999). What was once "tolerable" is now "intolerable" based on what we have learned about soil formation.
Soil erosion is a major global issue because of its adverse economic and environmental impacts (Lal, 1987, 1998, 2003; Pimentel et al., 1987, 1995). Lal (1998) stated:

Economic impacts on productivity may be due to direct effects on crops/plants on-site and off-site, and environmental consequences are primarily off-site due either to pollution of natural waters or adverse effects on air quality due to dust and emissions of greenhouse gases. Off-site economic effects of erosion are related to the damage to civil structures, sedimentation of water ways and reservoirs, and additional costs involved in water treatment. On-site effects of erosion on agronomic productivity are assessed with a wide range of methods, which can be broadly grouped into three categories: agronomic/soil quality evaluation, economic assessment, and knowledge surveys.

Agronomic methods involve greenhouse and field experiments to assess erosioninduced changes in soil quality in relation to productivity. There is also a need to assess on-site impact of erosion in relation to soil loss tolerance, soil life, soil resilience or ease of restoration, and soil management options for sustainable use of soil and water resources (Lal, 1998). Restoration of degraded soils is a high global priority (Oldeman et al., 1991). If about $1.5 \times 10^{9}$ ha of soils in the world prone to erosion can be effectively managed to control soil erosion, it would improve air and water quality, sequester $C$ in the soil at the rate of about 1.5

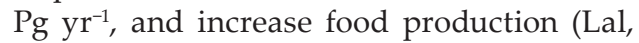
1995, 1998). Erosion-caused losses of food production are most severe in developing countries and elsewhere in the tropics.

Soil erosion is a complex process that depends on soil properties, ground slope, vegetation, and rainfall amount and intensity. Changes in historical land use, associated with intensive tillage, are widely recognized as accelerating soil erosion, and it has been long recognized that erosion in excess of soil generation would eventually result in decreased agricultural potential (Lal, 1998; Lal et al., 2007; Pimentel et al., 1987). Montgomery (2007) concluded that "erosion rates from conventionally plowed agricultural fields averaged 1-2 orders of magnitude greater than rates of soil production, erosion 
under native vegetation, and long-term geological erosion." He concluded that "hill slope soil production and erosion evolve to balance geologic and climate forcing, whereas conventional plow-based agriculture increases erosion rates sufficiently to prove unsustainable." Montgomery (2007) concluded further that "no-till agriculture produces erosion rates much closer to soil production rates and therefore could provide a foundation for sustainable agriculture." No-till, zero till, and direct seeding involves leaving crop residue on the soil surface instead of plowing it under. The seeds are inserted directly into the soil by a specialized drill. The layer of organic matter left on the soil surface acts as a surface mulch to promote infiltration and reduce runoff and erosion. In the 1970s, few farmers in the United States used no-till techniques, but by $2000,16 \%$ of the cultivated plants in the United States used no-till methods (Derpsch, 2001). Although no-till practices have been increasingly adopted in North and South America, approximately 5\% of the global cropland is managed by using no-till (Lal et al., 1998). Only a fraction of U.S. no-till cropping systems are permanent notill. The imbalance between agricultural soil loss and formation under both native vegetation and geologic time scale is that, given enough time, continued soil loss will become a critical problem for global agricultural production under conventional upland farming practices. With little new land that could be brought under sustained cultivation (FAOSTAT, 2009; Brown, 1994; Brown and Young, 1990; Chen, 1990; Fischer and Heilig, 1998; Gardner, 1996; Greenland et al., 1998; Young, 1999) and the projected increase in the global population (Ehrlich et al., 1993), the issue of long-term conventional (high-intensity tillage) agricultural sustainability will become an increasingly pressing issue.

Soil translocation from tillage operations has been identified as a source of soil erosion, which at specific landscape positions can be greater than the soil loss tolerance levels (Lindstrom et al., 1992; Govers et al., 1994; Lobb et al., 1995, 2007; Poesen et al., 1997). Soil translocation or tillage erosion is the net movement of soil downslope in response to the action of mechanical implements. The soil is not directly lost from the fields by tillage translocation or tillage erosion; rather, it is moved away from the convex slopes and deposited in concave slope positions. The loosened soil is redistributed as a result of the tillage tool and gravitational forces interacting. Lindstrom et al. (1992) showed that soil movement on a convex slope in southwestern Minnesota could result in a soil loss of approximately $30 \mathrm{t} \mathrm{ha}^{-1} \mathrm{yr}^{-1}$ from annual moldboard plowing. Lobb et al. (1995) estimated soil loss in southwestern Ontario from a shoulder position to be $54 \mathrm{t} \mathrm{ha}^{-1} \mathrm{yr}^{-1}$ from a tillage sequence of moldboard plowing, tandem disk harrow, and a C-tine cultivator. In this case, tillage erosion, as estimated through resident cesium-137, accounted for at least $70 \%$ of the total soil loss. Tillage speed increases the rate of tillage erosion nonlinearly (Lobb et al., 1995; Lindstrom et al., 2000). Schumacher et al. (1999) concluded that tillage erosion resulted in more soil loss in the shoulder position, while soil loss from water erosion occurred primarily in the mid to lower backslope position. The decline in soil productivity was greater when both processes were combined compared to either process acting alone. The net effect of soil translation from the combined effects of both tillage and water erosion was increased spatial variability of crop yields, which led to a decline in overall soil productivity (Schumacher et al., 1999).

\section{Agriculture's Impact on Greenhouse Gases}

Agricultural production also interacts with the environment on a global scale, and especially on global climate change. It is clear that agricultural production creates greenhouse gases (Reicosky et al., 2000) and releases $\mathrm{CO}_{2}$ during and after tillage (Reicosky and Lindstrom, 1993, 1995; Ellert and Janzen, 1999). If agriculture production grows to keep pace with the food demand, it will likely add further to the greenhouse gas problem. There is a relatively high degree of consensus among scientists that the average temperature of the Earth is increasing. There is some disagreement about the extent to which global warming has already occurred and about the extent to which human activities are responsible for the increase in greenhouse gases that cause global warming. Agriculture is a relatively small player contributing to greenhouse gases (Lal, 1999a). The three main greenhouse gases from agriculture that may cause global warming are $\mathrm{CO}_{2}$, methane $\left(\mathrm{CH}_{4}\right)$, and nitrous oxide $\left(\mathrm{N}_{2} \mathrm{O}\right)$ (Reicosky et al., 2000). The increased mechanization in intensive agriculture in addition to the petrochemicals used raises 
concern that energy use in agriculture will become an environmental problem. Chen (1990) reported that agricultural production accounts for only $3.5 \%$ of commercial energy use in developed countries and 4.5\% in developing countries.

Agriculture affects the condition of the environment in many ways, including impacts on global climate change through the production of greenhouse gases (Robertson et al., 2000). In 2004, the USEPA estimated that agriculture contributed approximately $7 \%$ of the U.S. greenhouse gas emissions (in carbon equivalents, or CE), primarily as $\mathrm{CH}_{4}$ and $\mathrm{N}_{2} \mathrm{O}$. While agriculture represents a small but relevant source of greenhouse gas emissions, it has the potential, with new practices, to also act as a sink, tying up, or sequestering, $\mathrm{CO}_{2}$ from the atmosphere in the form of soil $\mathrm{C}$ (Lal, 1999a). Lal (1999a) stated, "Estimates of the potential for agricultural conservation practices to enhance soil $\mathrm{C}$ storage range from 154-368 million metric tons (MMTCE), which compare to the 345 MMTCE of reduction proposed for the U.S. under the Kyoto Protocol." Thus, agricultural production systems can be manipulated for the dual benefits of reducing greenhouse gas emissions and enhancing $C$ sequestration, which contributes to increased productivity and environmental quality.

\section{Tillage versus No-Tillage?}

\section{Tillage and Its Role in Crop Production}

Tillage has many roles in crop production (Cornish and Pratley, 1987; Titi, 2003; Reicosky and Allmaras, 2003). The concept of tillage systems combines various aspects of tilling, planting, managing residue, and applying pesticides and fertilizers. Because of the number and diversity of components in tillage systems, it is difficult to give any one system a meaningful name or very precise definition (Reeder and Westermann, 2007). Systems can be identified according to their ultimate objective, whether it is conventional or conservation tillage, and sometimes they are described by the primary tillage implement used (e.g., whether it's a moldboard plow or a chisel plow). The name problem often is compounded because the definitions differ between geographic regions. Different names may be used to identify a similar tillage system in different parts of the country. Listing all the operations in the system results in the most accurate description as described in Reicosky and Allmaras (2003).

Tillage can have a major impact on soil functions and soil quality (Karlen et al.,1994a, 1994b; Reicosky, 1997). Warkentin (2001) discussed how alteration of soils by tillage changes the sustainability of soil functions. Soil tillage presents an enigma in thinking about soil sustainability in ecosystems. There is a several-thousand-year history of gradually increasing the disturbance of ever-greater volumes of soil (Lowdermilk, 1953; Gebregziabher et al., 2006; Lal et al., 2007) that gave the perception these tillage changes increased crop production. Specific soil uses, specific soils, characteristics of the site, and whether short or long-term changes are being evaluated determine the effects of tillage in agroecosystems. The largest effects of tillage are increased recycling rates and long-term decreases in porosity and diversity of habitat. The only benefits of tillage in annual crop production appear to be a temporary improvement of water and oxygen conditions in a seedbed and the destruction of competing plant species (Warkentin, 2001). Environmental concerns such as water quality, diversity of habitat, storage of carbon and nitrogen, and water partitioning are all negatively affected by tillage.

The most widely recognized function of tillage is seedbed preparation. Seed placement requires some form of tillage; even in no-till crop production systems, some soil must be disturbed to place the seed. Tillage has been used for thousands of years to release nutrients from the soil through accelerated mineralization of organic matter and to incorporate nutrients found in manures and crop residues. More recently, equipment has been developed to inject manures, commercial fertilizers, and other amendments into the soil. Tillage, in the form of cultivation, has been used extensively in the past to control weeds and insects. The recent development and use of commercial pesticides has greatly reduced the use of tillage. The widespread adoption of no-till/zero till systems in North America has been largely attributed to the availability of cost-effective glyphosate for weed control. With increasing interest in 
limiting or eliminating pesticide use in crop production, a return to more intensive tillage systems can be expected if soil erosion concerns are addressed. Tillage is also used to manage soil moisture (e.g., hilling row crops) and soil structure (breaking up soil crusts and alleviating soil compaction). Possibly the best example of a farm management practice which is not thought of as tillage but results in significant soil disturbance is the harvesting of root crops such as potatoes and sugar beets.

More farmers have been adopting no-till farming to capture efficiencies in crop production, saving money, time, and energy; to stop the loss of valuable topsoil by erosion; and to curb the runoff of sediment, fertilizers, and pesticides into rivers, lakes, and eventually oceans. Despite the benefits of no-till, adoption worldwide remains low at less than 7\% (Derpsch, 2001). A balanced evaluation of the sustainability of no-till agricultural systems describing advantages and disadvantages is warranted and must address challenges, including different equipment, pest management strategies, crop rotation, and fertility management, all which contribute to a steep learning curve for farmer adoption. The future of no-till farming will address global climate change, population growth, hunger and food nutrition, energy conservation and biofuels, environmental degradation, endangered species, pesticide use, genetically modified organisms and crop diversification (Phillips and Young, 1973). Huggins and Reganold (2008) stated, "No-till is not a cure-all; rather, no-till is a component of a larger vision of sustainable agriculture that is continually evolving and where diversity of farming methods from no-till to organic is healthy." Future no-till farming will need to employ more diverse pest management strategies, including biological, physical, and chemical measures to lessen the threat of pesticide resistance. Greater diversity of economically viable crops would also advance no-till farming and its adoption. There is a need to move away from intensive annual tillage, primarily monoculture farming, such as current wheat- and corn-based production, toward integration of perennial crop production practices, and precision technologies into no-till and conservation tillage systems.

In discussing various soil management practices that impact soil erosion, it is essential to understand the difference between conventional agriculture (conventional tillage) and conservation agriculture (conservation tillage with minimum soil disturbance). There are regional differences in the meaning of "conventional" that need to be clarified when discussing site-specific characteristics. Typically, conventional tillage over the last $30 \mathrm{yr}$ has consisted of moldboard plow, disk harrow, and field cultivator before planting. Reicosky and Allmaras (2003) described the difference between various tillage management systems presently used in North America. In no-till or zero till the soil is left undisturbed from harvest to planting except for nutrient and/or seed injection. Planting or drilling is accomplished in a narrow seedbed or slot created by coulter, row cleaners, disk openers, in-row chisels, or roto-tillers. Weed control is accomplished primarily with herbicides. Cultivation may be used for emergency weed control.

While this definition of no-till/zero till/ direct seeding may not be globally accepted, it serves to illustrate the conservation aspects of no-till come from minimum soil disturbance, continuous crop residue cover, and the use of diverse rotations and cover crops to protect the soil surface from erosion forces. The effect of no-till in reducing soil erosion rates that approximate the long-term rates of soil production suggests a more sustainable system (Montgomery, 2007).

No-till has the potential to deliver benefits that are increasingly desirable in a world facing population growth, environmental degradation, rising energy costs, and climate change, among other daunting challenges. The terminology being developed for such systems is Conservation Agriculture (CA) (FAO, 2009). Conservation agriculture implies conformity with all three principles supporting CA defined by FAO (2009) as: “ 1) minimum soil tillage disturbance, 2) diverse crop rotations and/or cover crops, and 3) continuous plant residue cover." Others are promoting the integration of crop and livestock production and controlled traffic into the vision of CA. The foundation underlying the three main principles is how they interact with and contribute to soil carbon, the primary determinant of soil quality. Conservation agriculture includes concepts of no-till, zero till, and direct seeding as the ultimate form of CA. But no-till is not a cure-all; rather it is part of a larger system, requiring higher-level 
management, evolving vision of sustainable agriculture, in which a diversity of farming methods is considered healthy. Ultimately, all farmers should integrate all aspects of conservation agriculture with no-till on their farms for sustainability.

\section{Tillage and the Environment}

The primary environmental benefits of all soil management practices are, first and foremost, improvements in soil and water quality. Of all farm management practices, tillage may have the greatest impact on the environment. Reicosky (2008) stated:

Tillage, by affecting crop production, affects the environment: crop productivity affects the production and consumption of $\mathrm{CO}_{2}$, the production of biomass above and below ground, the uptake of soil water and its transpiration, and the efficiency of cropping inputs such as fertilizer and pesticides. In addition to its effects on crop production, tillage also affects a variety of soil biophysical properties and processes that impact the environment.

Tillage releases $\mathrm{CO}_{2}$ and mixes soil and crop residue to allow rapid decomposition of SOM (Reicosky and Lindstrom, 1993, 1995; Reicosky, 1997, 2002; Ellert and Janzen, 1999). In this way, tillage is a "double negative," rapidly releasing carbon from the soil and contributing to the increase in the atmospheric $\mathrm{CO}_{2}$ and an enhanced greenhouse gases effect. Tillage under windy conditions loses soil carbon faster than under low wind speeds (Reicosky et al., 2008). Reicosky et al. (2008) stated that tillage "affects wind, water and tillage erosion, leaching and runoff, greenhouse gas emissions, pesticide sorption and degradation, as well as other biophysical processes. Tillage intensity, by affecting the amount of crop residue on the soil surface and how that residue is distributed on and anchored to the soil, and by affecting the size of soil aggregates and their stability, has a large impact of wind and water erosion." Tillage, through the action of soil disturbance and the downward force of gravity, causes the slow progressive downslope movement of soil, i.e., tillage erosion (Lobb et al., 1995). Soil erosion results in the redistribution of soil within fields and losses from fields. Typically, in cultivated topographically complex landscapes soil loss is most severe on hilltops.

Huggins and Reganold (2008) concluded that "no till has the potential to deliver a host of benefits that are increasingly desirable in the world facing population growth, environmental degradation, rising energy costs and climate change." But they also stated that "no-till is not a cure-all; because such a thing does not exist in agriculture." Huggins and Reganold (2008) considered no-till as part of a larger component of sustainable agriculture in which the different farming methods from no-till to organic and combinations are considered healthy. All farmers should integrate all aspects of conservation agriculture, and no-till if feasible, on their farms for environmental protection (Reicosky and Saxton, 2007a,b; Reicosky, 2008).

Intensive tillage influences SOC dynamics and storage. Studies have shown that the adoption of no-till leads to an accumulation of SOC at or near the soil surface (0-10 cm; see West and Post, 2002; Deen and Kataki, 2003). There have been several meta-analyses and scientific literature reviews on no-till vs. conventional tillage on SOC in world soils (e.g., Six et al., 2002, 2004; West and Post, 2002; Alvarez, 2005), in which various forms of conventional tillage were considered (conventional tillage may involve noninversion primary tillage such as disk plowing or using a heavy cultivator, such as practiced in the Canadian prairies).

Furthermore, reducing tillage increases soil carbon sequestration compared with conventional moldboard plowing (Deen and Kataki, 2003). One of agriculture's main greenhouse gas mitigation strategies is soil carbon sequestration (Lal et al., 1998; Izaurralde et al., 2001) wherein crops remove $\mathrm{CO}_{2}$ from the atmosphere during photosynthesis, and nonharvested residues and roots are converted to soil organic matter, which is $58 \%$ carbon. About one-half of the overall potential for U.S. croplands to sequester soil carbon comes from conservation tillage, including no-till (Dick and Durkalski, 1997; Lal et al., 1998).

Soil carbon sequestration has benefits beyond removal of $\mathrm{CO}_{2}$ from the atmosphere. No-till cropping reduces fossil fuel use, reduces soil erosion, and enhances soil fertility and water-holding capacity. Beneficial effects of conservation tillage on SOC content may be short-lived if the soil is plowed 
even after a long time under conservation tillage (Pierce et al., 1994; Gilley and Doran, 1997; Stockfisch et al., 1999; Garcia et al., 2007; Quincke et al., 2007). Stockfisch et al. (1999) concluded that "organic matter stratification and accumulation as result of long-term minimum tillage were completely lost by a single inversion tillage in the course of a relatively mild winter." Several experiments in North America have shown more SOC content in soils of conservation tillage compared to plow till seed beds (Doran, 1980, 1987; Doran et al., 1987; Rasmussen and Rohde, 1988; Tracy et al., 1990; Havlin et al., 1990; Kern and Johnson, 1993; Lafond et al., 1994; Reicosky et al., 1995; Reicosky, 2001a,b). Liebig et al. (2005) reported "continuous cropping and no-tillage resulted in carbon accumulation of 0.27 $\mathrm{Mg} \mathrm{C} / \mathrm{ha} / \mathrm{yr}$, a value specific to the lower rainfall area of the U.S. Northern Plains."

Soil plays a key role in maintaining a balanced ecosystem and in producing quality agricultural products (Organization for Economic Co-operation and Development, 2001). There can be a significant time delay between recognizing soil degradation and developing conservation strategies to maintain soil health and crop productivity. The intensity of rainfall, degree of protective crop cover, slope, and soil type are the controlling factors of water erosion. The process of wind erosion is also controlled by climate (soil moisture conditions), crop cover, and soil type and involves detaching and transporting soil particles (mainly silt and fine sand) over varying distances. Loss of topsoil by any type of erosion also contributes to the loss of nutrients. Soil tillage practices can also contribute to erosion by moving soil on hilly landscapes, removing soil from the hilltop to the bottom (Lobb et al., 1995, 2007).

Without permanent no-till, many of the agronomic and environmental benefits are not realized (Grandy et al., 2006). Years of soil regeneration can be lost to a single inversion tillage event (Stockfisch et al., 1999). Social and agronomic challenges as well as political challenges continue to limit both the extent and rate of no-till development. These challenges should become an agricultural research priority that emphasizes integrated systems approach and long-term dynamics. Interdisciplinary solutions must address these complex problems so that no-till systems can be more extensively adopted and permanently maintained, thereby yielding their full agronomic, economic, social, and environmental potential. Although some carbon is sequestered (Smith et al., 2001) accelerated water erosion is responsible for

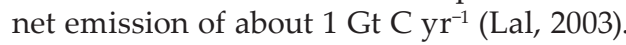
Leaving crop residues after grain harvest increases the carbon content of soil and controls erosion, but the benefits are lost if the biomass is plowed under because microorganisms quickly degrade residue $\mathrm{C}$ to $\mathrm{CO}_{2}$ (Reicosky et al., 1995). Essential nutrients as part of SOC disappear with its depletion. Thus, farmers require more fertilizer, irrigation, and pesticides to preserve yield while water quality can deteriorate when less SOC is available for natural filtering.

No-till agriculture reduces the loss of the SOC pool (Dalal et al., 1995; Sa et al., 2001; West and Post, 2002), with surface residues conserving soil water and inhibiting weeds. Soil C enhancement improves agronomic productivity (Bauer and Black, 1994) and resource-use efficiency of impoverished soils. The beneficial effects of enhanced SOC cannot be fully replaced by increased levels of fertilizer, especially in soils of the tropics (Kanchikerimath and Singh, 2001). No-till, in combination with mulching and crop rotation to enhance the SOC pool (Angers et al., 1995; Jenkinson, 1991; Smith and Powlson, 2000; Drinkwater et al., 1998; Uhlen and Tveitnes,1995), is also a viable strategy for sustainable management of soils of the tropics.

Tillage causes the release of the labile fraction soil organic matter from within the aggregates; plus the incorporation of the aboveground biomass leads to increased SOC availability for decomposition (Shepherd et al., 2001). As result, microbial activity increases, leading to accelerated $\mathrm{CO}_{2}$ emissions (Reicosky and Lindstrom, 1993; Ellert and Janzen, 1999) and N mineralization rates. Although some of the nitrate produced from tillage is taken up by the plants, the release of this $\mathrm{N}$ is often poorly synchronized with plant nitrogen needs, which usually do not peak for eight or more weeks after tillage, making the mineralized $\mathrm{N}$ highly susceptible to loss via leaching and denitrification. Associated with these changes in soil aggregation and organic matter availability are increases in soil temperature and oxygen concentration that further stimulate microbial decomposition. This process can be reversed by eliminating tillage, but the 
recovery of the aggregates and aggregateassociated carbon pools takes several years longer than the destruction that occurs with a single tillage event (Pierce et al., 1994; Stockfisch et al., 1999; Garcia et al., 2007; Grandy et al., 2006; Quincke et al., 2007). Clearly, tillage has an immediate and striking effect on soil fauna and biological processes (Calderón et al., 2001; Jackson et al., 2003), and even intermittent tillage of no-till systems may undermine efforts to restore soil physical and biological processes and sequestered carbon in the systems (Six et al., 2004).

Several years are often required before soil aggregate stability increases in no-till systems. As a result, compaction may limit growth and denitrification rates may be high due to anaerobic sites (Ismail et al., 1994; Six et al., 2004). Grandy et al. (2006) found substantial changes in soil aggregation within $31 \mathrm{~d}$ following tillage, suggesting that tillage per se, rather than the indirect effects of bare soils or plant community changes, destroyed soil aggregates. A handful of studies in different geographical regions demonstrated changes in the distribution of organic matter between soil size fractions and depths following tillage of long-term no-till soils (Tiessen and Stewart, 1983; Pierce et al., 1994; VandenBygaart and Kay, 2004). Soil aggregation changes rarely have been studied following this conversion from no-till. Soil aggregation may be the single best indicator of the agronomic and environmental effects of tillage because it influences soil structure, soil permeability, and water-holding capacity, as well as soil organic matter turnover in nutrient cycling (Jastrow et al., 1996; Grandy et al., 2002; Shaver et al., 2003).

Historical data have demonstrated the degradation of accelerated soil erosion in agricultural societies to the extent that episodes of severe soil erosion were associated with the rise and decline of civilization in the Middle East (Lowdermilk, 1953; Gebregziabher et al., 2006; Lal et al., 2007). Montgomery (2007) analyzed historical data and concluded that the erosion rates from conventionally plowed agricultural fields averaged one to two orders of magnitude greater than the rates of soil formation or long-term geological erosion. Losing soil faster than it can be generated is not a sustainable system and will eventually result in decreased agricultural production. Soil erosion rates in conventionally plowed fields can erode through a typical hillslope soil profile over time scales that are comparable to the longevity of some major civilizations. Montgomery (2007) stated that "no till agriculture produces erosion rates much closer to soil production rates and therefore could provide a foundation for sustainable agriculture."

In the past several decades, scientists have determined that measuring the soil concentrations of certain isotopes that form at a known rate permits direct quantification of soil production/formation rates. Applying this technique to soils in temperate regions Heimsath et al. (1999) found soil production rates ranging from 0.02997 to $0.08001 \mathrm{~mm}(0.00118-0.00315$ inch) per year. As such, it takes 300 to 850 yr to form $25.4 \mathrm{~mm}$ of soil in these places. Montgomery's (2007) global compilation of data revealed an average rate of 0.01701 to $0.03607 \mathrm{~mm}$ (0.00067-0.00142 inch) per year-equivalent to 700 to $1500 \mathrm{yr}$ to form $25.4 \mathrm{~mm}$ of soil. With natural soil production rates of centuries to millennia per 25.4 $\mathrm{mm}$ and soil erosion rates of millimeters per century under plow-based agriculture, it would take just several hundred to a couple of thousand years to plow through the soil in these regions. This simple estimate predicts remarkably well the life span of major agricultural civilizations around the world. With the exception of the fertile river valleys along which agriculture began, civilizations generally lasted 800 to $2000 \mathrm{yr}$, and geo-archaeological studies have now shown a connection between soil erosion and the decline of many ancient cultures (Lowdermilk, 1953; Gebregziabher et al., 2006; Lal et al., 2007).

No-till offers some economic advantages to farmers. The number of passes over a field needed to establish and harvest a crop with no-till typically decreases, requiring 50 to $80 \%$ less fuel and 30 to $50 \%$ less labor than tillage-based agriculture, significantly lowering production costs per acre (Phillips and Phillips, 1984). Although specialized no-till seeding equipment can be expensive, running and maintaining intensive tillage equipment is no longer necessary, lowering the total capital and operating costs of machinery required by up to 50\% (Phillips and Young, 1973; Phillips and Phillips, 1984). With these savings in time and money, farmers can be more 
competitive at smaller scales, or they can expand and farm more land, sometimes doubling farm size using the same equipment and labor. Many farmers appreciate that the time they once devoted to rather mundane tillage tasks they can instead spend on more challenging aspects of farming, family life, or recreation, thereby enhancing their quality of life.

Future no-till agriculture will need to employ more diverse pest and weed management strategies, including biological, physical, and chemical measures to lessen the threat of pesticide resistance. Crop rotation is already helping no-till's war on pests and weeds by helping to break up the weed, pest, and disease cycles when one species is grown continuously (Calegari et al., 2008). The capacity to grow a diverse selection of economically viable crops would advance no-till farming and make it more appealing to farmers. Experts continue to debate the merits of growing fuel on farmland, but if society decides to expand biofuel crops, we will need to consider using no-till with diverse crop rotation to produce them sustainably (Moebius-Clune et al., 2008). Development of alternative crops for bioenergy production on marginal lands, including perennials such as switchgrass, could complement and promote no-till farming, as would perennial grain food crops currently under development.

\section{Soil Carbon, Nitrogen, and Nutrient Cycling}

The importance of the soil carbon cycle is often overlooked in traditional agricultural studies because the primary focus is on the crop yield, which is not subject to known carbon limitations, and on those nutrients such as nitrogen that do limit productivity. The decomposition portion of the carbon cycle governs many agronomic processes that occur below ground and manifest themselves above ground. Microorganisms control the decomposition of $\mathrm{C}$, and their activity regulates nutrient cycling in soils. Even though the consequences of their activities can be quite obvious, the presence of most microorganisms is usually taken for granted in cropping systems. In studies of ecosystems, microorganisms are generally considered not as organisms, in an autoecological sense, but as disembodied rates and pools of nutrients. A better mechanistic understanding of many ecosystem processes could be obtained from knowledge of microbial species composition, physiology, and metabolism; of the factors controlling microbial populations and activities; and of the spatial and temporal distribution of microorganisms.

Soil humus comprises a large and stable pool of soil organic matter (SOM); hence a better understanding of the fate of $C$ in soil humic fractions can provide valuable information for the development of alternative tillage practices that may lead to long-term soil C sequestration. Murage and Voroney (2008) reported tillage effects on the dynamics of native $C(C 3-C)$ and corn-derived $C$ (C4-C) in fulvic acid (FA), humic acid (HA), and humin fractions:

Humic substances were extracted from soils cropped with corn for 11 yr and managed under either $55 \mathrm{yr}$ of conventional tillage (CT) or no-tillage (NT). No-tillage resulted in higher proportions of $\mathrm{C} 4-\mathrm{C}$ in the upper $5 \mathrm{~cm}$ and generally lower $\mathrm{C} 4-\mathrm{C}$ proportions below $5 \mathrm{~cm}$ than CT. Up to 31, 27, and $34 \%$ of C4-C were assimilated into FA, HA and humin fractions, respectively, indicating that even the humin fraction, often described as passive, old, or resistant, acted as a sink for recently added $\mathrm{C}$, and that it is heterogeneous with some young components. Recovery of large proportions of $\mathrm{C} 3-\mathrm{C}$ in the humic fractions demonstrated their importance in the long-term stabilization of SOM. Within each sampling depth, there were no unique differences in the distribution of $\mathrm{C} 3-\mathrm{C}$ among the three humic fractions, suggesting similar turnover of $\mathrm{C} 3-\mathrm{C}$ in all the fractions.

These results show the subtle impact of intensive tillage on new and old carbon cycling in our production systems that awaits further research (Angers et al., 1997; Huggins et al., 2007).

While the adoption of no-till can lead to the accumulation of SOC in the surface soil layers, a number of recent studies have shown that this effect is sometimes partly or completely offset by greater SOC content near the bottom of the plow layer 
under full-inversion tillage (FIT) (Six et al., 2002; West and Post, 2002; Baker et al., 2007; Blanco-Canqui and Lal, 2008; Christopher et al., 2009). Angers and Eriksen-Hamel, (2008) reviewed the literature in which SOC profiles had been measured under paired no-till and FIT situations. Full-inversion tillage is inferred as moldboard plow as primary tillage likely followed with some form of secondary tillage (Reicosky and Allmaras, 2003). Angers and Eriksen-Hamel (2008) found profiles of SOC had to be measured to at least $30 \mathrm{~cm}$, and in most studies, SOC content was significantly greater under no-till than full-inversion tillage in the surface soil layers. At the 21- to $25-\mathrm{cm}$ soil depth, which corresponds to the mean plowing depth for the data set $(23 \mathrm{~cm})$, the average SOC content was significantly greater under FIT than no-till. The relative accumulation of SOC at depth under FIT could not be related to soil or climatic variables. Furthermore, the organic matter accumulating at depth under FIT was present in relatively stable form, but this hypothesis and the mechanisms involved require further investigation. Significant differences in SOC stocks between FIT and no-till situations occur at the soil surface but also at depth, which further highlights the importance of taking into account the whole soil profile when comparing soil C stocks (Baker et al., 2007; Blanco-Canqui and Lal, 2008; Christopher et al., 2009). The accumulation of SOC at depth in FIT situations is occurring at the bottom of the plow layer, but to some extent also below it. The greater SOC content at depth under FIT did not completely offset the gain under no-till in the surface horizon, with the net result that the average SOC stocks were greater under no-till than under FIT. The extent, mechanisms, and factors controlling SOC stabilization at depth require further investigations for all types of tillage implements, especially inversion tillage.

Sanchez et al. (2004) investigated the impact of cropping system management on $\mathrm{C}$ and $\mathrm{N}$ pools, crop yield, and $\mathrm{N}$ leaching in a long-term agronomic experiment in southwest Michigan. Four management types ranging from conventional to transitional organic were applied to two crop sequences with and without legume cover crops. Using compost as a fertility source and reducing the use of herbicides and other chemicals resulted in long-term changes in soil organic matter pools. Mineralizable N varied within the rotation, tending to increase after soybean and decrease after corn production in all systems. Corn yield was closely associated with 70-d N mineralization potential, being greatest for first-year corn with cover crop and least for continuous corn without cover crop under all management types. Fall nitrate level and nitrate leaching were higher for commercially fertilized corn than for any other crop or for compost-amended corn. This unique longterm agriculture experiment shows how a production system integrating reduced chemical inputs and a well-designed crop rotation can produce higher yield and lower leaching than a comparable conventional system. Organic $C$ and $N$ storage increased up to 43 and $33 \%$ in the integrated compost and transitional organic systems, which decreased the need for additional fertilizers and should tend to improve soil structure and physical condition. Legume cover crops were particularly important within wheat stubble and resulted in a 13\% increase in first-year corn yield.

The results of Sanchez et al. (2004) are general and can be applied to corn-based agroecosystems anywhere. In general, agroecosystems that make better use of short- and long-term $\mathrm{C}$ and $\mathrm{N}$ pools will tend to be more productive and environmentally sustainable than systems that rely on heavy applications of chemical fertilizers and herbicides. Applying a properly structured diverse crop rotation to soils under limited tillage, utilizing legume cover crops where appropriate, taking an integrated pest management approach to weed management, and supplementing fertility with animal waste products all tend to increase labile soil organic $\mathrm{C}$ and N. Sequestering $C$ in soils has a significant impact on the global $\mathrm{C}$ cycle and enhances the mineralizable forms of $\mathrm{C}$ and $\mathrm{N}$, resulting in greater soil $\mathrm{N}$ supplying and recycling capacity. This may be useful in all production systems but is essential where synthetic fertilizers are not the primary N source (Russell et al., 2006; Khan et al., 2007). Widespread adoption of the strategies suggested in this study have the potential to improve soil and water quality without affecting yield and are likely to contribute to a cleaner environment on a global scale. 


\section{Biomass and Bioenergy Concerns}

Biofuels have huge potential for renewable energy development. With the global population growing, the demand for food and energy is intensifying. Despite our best efforts, intensive agricultural practices are still compromising the natural resource base that we rely on for food production (Larson, 1979). Increased land area required for producing biomass for energy use may result in less land available for food production and, hence, less food production, possibly endangering global food security (Giampietro et al., 1997). Using a modeling analysis, Wolf et al. (2003) showed that when a high input system of agriculture is applied, 55\% of the present global agricultural land area is needed for food production to the year 2050. The remaining $45 \%$ can be used for other purposes, such as biomass production. On the other hand, if a low input system is applied at the global scale for food production, there is no land available for biomass production. Unfortunately, Wolf et al. (2003) did not address production sustainability and the long-term implications of potential soil degradation associated with corn biomass removal (soil carbon depletion), a major environmental concern (Grigal and Berguson, 1998; Mann et al., 2002; Wilhelm et al., 2004, 2007; Lemus and Lal, 2005; Johnson et al., 2006a,b, 2007; Hoskinson et al., 2007; Graham et al., 2007).

The basic challenge for soil conservation is not biofuel use, but the way in which biomass is produced (Plieninger and Bens, 2007). Plieninger and Bens (2007) stated, "Innovative land-use systems specifically designed for energy crops that have both high energy production per unit land area and support high structural and species diversity might offer a way to cope with this energy and environmental dilemma." Biofuels may be the renewable energy carrier with the highest relevance for biological conservation, but both conservation science and policy are just starting to understand the dimensions of the challenge (Larson, 1979). Life cycle assessments for biofuels are very complex and highly controversial; the system limits in terms of included environmental parameters and steps of the production process are often not standardized, and assessments can hardly keep pace with the rapid changes in the field. Significant greenhouse gas emissions can be released in manufacture of nitrogen fertilizer inputs. Considering the choice of energy conversion, life-cycle assessments indicate that using biofuels for heat and electricity generation is generally superior to automotive fuels (Crutzen et al., 2007; Plieninger and Bens, 2007). In most cases energy crops are placed on fertile soils, where direct competition between food and fuel production arises. Currently there are few political and economic incentives for energy crops to encroach on marginal lands of high conservation value, although there is concern that seminatural grasslands might be converted to energy croplands with switchgrass (Liebig et al., 2005). Current energy cropping systems are largely derived from conventional intensive tillage agricultural and include monoculture crops and high inputs of synthetic nitrogen fertilizer. Crutzen et al. (2007) stated, "An estimated 83\% of the global land area is already under direct human influence, and further extending the human footprint on land may be accompanied by negative ecological concomitants." Innovative land-use systems, specifically designed for energy crops, that both have high energy productivity per area and support a high structural and species diversity are needed. Potential strategies comprise the diversification of crop rotations, reductions in mineral fertilizer and herbicide use, the use of a broader diversity of crop species and varieties, the design of mixed cropping systems, longer harvest intervals, and increased physical landscape structure. Efficient conservation standards for bioenergy could help to integrate ecological knowledge and thus direct bioenergy into pathways that are compatible with landscape protection, biodiversity, soil conservation, and cultural issues. Future policies that provide better incentives for biofuels with a high energy efficiency and a high potential for greenhouse gas emission reduction must accommodate the long-term implications of potential soil degradation associated with corn biomass removal (soil carbon depletion) that is of major environmental concern (Mann et al., 2002; Reicosky et al., 2002; Wilhelm et al., 2004, 2007; Lemus and Lal, 2005; Johnson et al., 2006a,b, 2007; Graham et al., 2007).

Above- and belowground crop biomass provide the organic carbon input for building SOM (Johnson et al., 2006a). Soil organic matter is responsible for many of the characteristics associated with highly 
productive soils (Doran et al., 1998; Doran, 2002; Janzen et al., 1998). Soil organic matter improves soil aggregation and aggregate stability (Gollany et al., 1991; Tisdall and Oades, 1982; Tisdall, 1996; Six et al., 1998), which subsequently impacts soil infiltration, water-holding capacity (Gollany et al., 1992), aeration, bulk density (Gollany et al., 1992), penetration resistance, and soil tilth. Mann et al. (2002) reviewed existing literature to evaluate the major environmental impacts potentially associated with stover harvest from reduced tillage corn production sites. Mann et al. (2002) stated that "more information is needed on several topics to determine potential long-term effects of residue harvest including: (1) erosion and water quality, especially pesticides and nitrate; (2) rates of transformation of different forms of SOC; (3) effects on soil biota; and (4) SOC dynamics in the subsoil. Soil organic matter also impacts chemical properties including $\mathrm{pH}$, nutrient availability and cycling, cation-exchange capacity and buffer capacity." This long list of soil carbon benefits from the plant biomass makes it difficult to understand the combination of intensive tillage and removal of biomass for bioenergy as a truly sustainable production system. Experts continue to debate the merits of growing biomass for bioenergy on farmland, but if society decides to proceed with biofuel crops, we will need to consider using no-till with diverse crop rotation to produce them sustainably (Reicosky et al., 2002; Moebius-Clune et al., 2008).

Primarily, organic C inputs to soil are from the unharvested aboveground, belowground biomass and rhizodeposition from cash crop plants and cover crops, and other organic inputs (e.g., animal manure). Studies have shown that manure application increased SOC and nutrient status in the soil (Webster and Goulding, 1989; Collins et al., 1992; Rochette and Gregorich, 1998) and labile carbon pools (Aoyama et al., 1999; Mikha and Rice, 2004). Total corn rootderived $\mathrm{C}$ ( $\mathrm{C}$ in root biomass plus that in rhizodeposition) contributes from 1.5 times to more than 3 times more $\mathrm{C}$ to SOC than shoot-derived C (Balesdent and Balabane, 1996; Wanniarachchi et al., 1999; Allmaras et al., 2004; Wilts et al., 2004; Hooker et al., 2005). Hooker et al. (2005) attributed the difference to dissimilar C cycling rates of shoot and root material. Wilhelm et al. (2004) noted a critical caveat that even though a larger percentage of root $\mathrm{C}$ is incorporated into SOC, it does not negate the importance of shoot biomass in building and maintaining SOC. Despite the importance of roots to the formation of SOC, there is little information on total biomass (above and belowground) needed to maintain or build SOC. Most studies include only aboveground biomass (Reicosky et al., 2002; Johnson et al., 2006a; Wilhelm et al., 2007).

Johnson et al. (2006a) estimated the minimum amount of biomass necessary to prevent loss of SOC based on literature values from long-term field-studies. These estimates need to be improved to account for climatic and soil type effects. They are, however, the first published estimates of minimum biomass required to maintain productivity (i.e., SOC) and provide general guidelines to the cellulosic ethanol industry. These guidelines are stated as absolute amount of biomass input, not as a portion of the amount produced, as is more commonly stated, especially for preventing erosion. The soil C cycle works slowly. Even though SOC decomposition rates fluctuate with seasonal temperature and water condition, over time a mean rate of biomass input is required to replace $C$ released from the soil system. The estimates by Johnson et al. (2006a; 2006b) are from limited data in the literature and based on long-term (mean) inputs. Crop yields fluctuate over seasons depending on the weather extremes.

Erosion prevention and C sequestration benefits associated with cover crop use make their use in conjunction with harvesting biomass appealing, provided that the added complexity to scheduling equipment and labor to accomplish additional tasks is not limiting. Preventing soil loss from erosion and increasing the influx of $\mathrm{C}$ to the soil by extending the photosynthetic season builds SOM and improves soil quality (Dabney et al., 2001). Cover crops in conjunction with conservation tillage practices sequester more $\mathrm{C}$ than conservation tillage alone (Causarano et al., 2006; Calegari et al., 2008). The $\mathrm{C}$ input from cover crops was linearly related to soil C concentration (Kuo and Jellum, 2002), consistent with others who reported linear increases in soil C with increased C inputs (Larson et al., 1972; Paustian et al., 1997; Follett et al., 2005). The question remains as to whether cover crops provide sufficient 
biomass to prevent erosion and loss of SOM in a system removing biomass for bioenergy (Moebius-Clune et al., 2008).

An important requirement for any biomass cropping is the sustainability of the production system (Volk et al., 2004). While the withdrawals of nutrients are probably small and the soil $\mathrm{C}$ contents will rather slightly increase than decrease under most scenarios (Lemus and Lal, 2005), soil fertility depletion can be an issue and has been the justification to fertilize bioenergy plantations with the ash from combustion residue (Park et al., 2005). Limited information on the impacts of tillage with residue removal suggests that tillage is more of a factor in carbon loss than the biomass return for soil carbon input (Karlen et al., 1994a, 1994b; Hooker et al., 2005; Moebius-Clune et al., 2008).

The minimum detectable difference in SOC was calculated as a function of variance and sample size for SOC changes after 5 yr under a herbaceous bioenergy crop (Garten and Wullschleger, 1999). The authors showed that the smallest difference that could be detected was about $1 \mathrm{t} \mathrm{C} \mathrm{ha}^{-1}$, and this could only be done using exceedingly large sample sizes. The minimum difference that could be detected with a reasonable sample size and a good statistical power (90\% confidence) was 1 t C ha- ${ }^{-1}$ Most agricultural practices will not cause the soil to accumulate this during a 5-yr commitment period (Smith et al., 1998).

Loss of fertility is a major impact of soil erosion, especially in old and highly weathered soils in which SOC and plant nutrients are concentrated in the upper few centimeters of the soil profile. Loss of soil fertility is the principal cause of yield decline on eroded soils (Peterson, 1964). Nutrient losses are more severe on arable lands, where supplemental fertilizers applied can have a masking effect on crop yields (Cleveland, 1995). There are two mechanisms of fertility decline by erosion (Helvey et al., 1985). The greatest nutrient losses occurred with mass soil movements and the soil deposited in alluvial fans. High nutrient losses occurred in soils that did not receive chemical fertilizers. Controlled biomass burning may, in some cases, reduce risks of runoff and nutrient losses compared with uncontrolled burning. In Spain, Mangas et al. (1992) observed that nutrient loss in runoff after burning was between 8 and 35\% of that of the previous year, while the volume of runoff was only $3 \%$, implying greater concentration of nutrients in runoff. Wallingford (1991) prepared a nutrient balance sheet for major U.S. crops and observed the $\mathrm{N}$ budget to be slightly positive and stable in the 1990s, the P budget was negative after being positive in the 1960s and 1970s, and the $\mathrm{K}$ budget was strongly negative. This budgeting exercise, however, did not take into consideration the losses due to erosion that in some cases may be substantial. Experiments conducted on Vertisols (fine, montmorillonitic, thermic, Udic Pellusterts) in east-central Texas showed that losses of plant nutrients in no-till and chisel till treatments were 3.8 and $8.1 \mathrm{~kg} \mathrm{ha}^{-1}$ for $\mathrm{N}$ and 0.8 and $1.5 \mathrm{~kg} \mathrm{ha}^{-1}$ for $\mathrm{P}$, respectively (Chichester and Richardson, 1992). The combination of nutrient and soil loss with erosion is a double negative exacerbated by intensive tillage.

\section{Summary and Conclusions}

Humans require a secure and renewable natural-resource base to sustain their basic needs for future social and economic activity. However, while deriving natural resources from the terrestrial biosphere, humans also inadvertently modify their environment. The 20th century saw an expanding human population, increasing agricultural yields, and a decreasing land-resource base. To feed the world population, agriculture has expanded using intensive tillage, resulting in a greater impact on the environment, human health, and biodiversity. But, given our current knowledge of the planet's capacity, we now realize that producing sufficient food is not enough-it must also be done sustainably. Farmers need to generate adequate crop yields of high quality, conserve natural resources for future generations, make enough money to live on, and be fair and equitable to their workers and community. No-till farming is one system that has the potential to help realize this vision of a more sustainable agriculture. As with any new system, there are challenges and tradeoffs. Nevertheless, growers in some parts of the world are increasingly abandoning their plows. Leaving crop residues on the soil surface provides soil protection and helps to increase water infiltration and limit 
runoff. Decreased runoff, in turn, can reduce pollution of nearby water sources with transported sediment, fertilizers, and pesticides. The residues also promote water conservation by reducing evaporation in drier areas. In instances where water availability limits crop production, greater water conservation can mean higher-yielding crops or new capabilities to grow alternative crops.

The balance between agricultural productivity and environmental quality relies on proper resource management. The sun, soil, water, and air are our primary resources for food security. The increasing global population requires improved management of these resources and challenges our human intellectual capacity to meet the food security needs of all society. As the global population continues to expand, our food security becomes a little more challenging when we recognize that we have a finite amount of land area for agricultural production. The increasing productivity required to meet this increasing demand for food must be done in an environmentally friendly way to maintain our quality of life. Improved soil management practices with emphasis on SOC to maintain soil physical, chemical, and biological properties to minimize soil degradation are urgently needed. Many of the environmental issues of intensive agriculture can be directly related to intensive tillage and its unintended consequences. Intensive tillage destroys the soil structural integrity, the natural soil fauna habitat, releases $\mathrm{CO}_{2}$ and enhances soil mineralization and breakdown of SOM, causes tillage erosion on sloping lands, and sets the soil up for wind and water erosion that all contribute to degradation of soil, water, and air quality. There is compelling evidence that intensive tillage of our agricultural landscapes is responsible for environmental degradation in our agricultural ecosystems.

To conserve resources for future generations, we need alternatives to conventional farming practices. No-till systems simultaneously reduce the erosive force of runoff and increase the ability to hold soil in place, making these methods remarkably effective at curbing erosion. Although the effect of notill on erosion rates depends on a number of site-specific factors, such as the soil type and crop, less intensive tillage can decrease soil erosion rates close to soil formation rates. There's a definite need for improved best management practices that lead to decreased tillage intensity and improved plant management techniques for capturing solar energy in the form of photosynthesis and for returning nutrients and carbon to the soil. While our society has a tremendous need for bioenergy from biomass, caution is suggested until the long-term implications of biomass and carbon removal for our food security are understood. More troubling, the environmental degradation caused by agriculture will likely worsen as the hungry human population grows to eight billion or ten billion in the coming decades. The need for critical research to develop the best management practices to maintain this delicate balance between agricultural productivity and environmental quality cries for our attention with more emphasis on reducing tillage intensity.

\section{Acknowledgment}

The authors gratefully acknowledge the assistance of Beth Burmeister for typing assistance, editorial comments, and crosschecking literature citations.

\section{References}

Allmaras, R.R., D.R. Linden, and C.E. Clapp. 2004. Corn residue transformations into root and soil carbon as related to nitrogen, tillage, and stover management. Soil Sci. Soc. Am. J. 68:1366-1375.

Alvarez, R. 2005. A review of nitrogen fertilizer and conservation tillage effects on soil organic carbon storage. Soil Use Manage. 21:38-52.

Angers, D.A., M.A. Bolinder, M.R. Carter, E.G. Gregorich, C.F. Drury, B.C. Liang, R.P. Voroney, R.R. Simard, R.G. Donald, R.P. Beyaert, and J. Martel. 1997. Impact of tillage practices on organic carbon and nitrogen storage in cool, humid soils of eastern Canada. Soil Tillage Res. 41:191-201.

Angers, D.A., and N.S. Eriksen-Hamel. 2008. Full-inversion tillage and organic carbon distribution in soil profiles: A meta-analysis. Soil Sci. Soc. Am. J. 72(5):1370-1374

Angers, D.A., R.P. Voroney, and D. Côté. 1995. Dynamics of soil organic matter and corn residues as affected by tillage practices. Soil Sci. Soc. Am. J. 59:1311-1315.

Aoyama, M., D.A. Angers, A. N'Dayegamiye, and N. Bissonnette. 1999. Protected organic matter in waterstable aggregates as affected by mineral fertilizer and manure applications. Can. J. Soil Sci. 79:419-425.

Baker, J.M., T.E. Ochsner, R.T. Venterea, and T.J. Griffis. 2007. Tillage and soil carbon sequestration-What do we really know? Agric. Ecosyst. Environ. 118(1-4):1-5.

Balesdent, J., and M. Balabane. 1996. Major contribution of roots to soil carbon storage inferred from maize cultivated soils. Soil Biol. Biochem. 28:1261-1263.

Bauer, A., and A.L. Black. 1994. Quantification of the effect of soil organic matter content on soil productivity. Soil Sci. Soc. Am. J. 58:185-193.

Beinroth, F.H., H. Eswaran, P.F. Reich, and E. Van den Berg. 1994. Land related stresses in agroecosystems. p. 131-148. In S.M. Virmani et al. (ed.) Stressed ecosystems and sustainable agriculture. Oxford \& IBH Publ. Co., New Delhi, India. 
Blanco-Canqui, H., and R. Lal. 2004. Mechanisms of carbon sequestration in soil aggregates. Crit. Rev. Plant Sci. 23(6):481-505

Blanco-Canqui, H., and R. Lal. 2008. No-tillage and soilprofile carbon sequestration: An on-farm assessment. Soil Sci. Soc. Am. J. 72:693-701.

Brown, L.R. 1994. Facing food security. p. 177-197. In L.R. Brown et al. (ed.) State of the world. Earthscan Publ., London.

Brown, L.R., and J.E. Young. 1990. Feeding the world in the nineties. p. 59-78. In L.R. Brown et al. (ed.) State of the world 1990: A Worldwatch Institute report on progress toward a sustainable society. Worldwatch Inst., Washington, DC.

Buringh, P. 1989. Availability of agricultural land for crops and livestock production. p. 69-83. In L.D. Pimentel and C.W. Hall (ed.) Food and natural resources. Academic Press, San Diego.

Calderón, F.J., L.E. Jackson, K.M. Scow, and D. Rolston. 2001. Short-term dynamics of nitrogen, microbial activity and phospholipid fatty acids after tillage. Soil Sci. Soc. Am. J. 65:118-126.

Calegari, A., W.L. Hargrove, D. Dos Santos Rheinheimer, R. Ralisch, D. Tessier, S. de Tourdonnet, and M. de Fatima Guimarães. 2008. Impact of long-term notillage and cropping system management on soil organic carbon in an Oxisol: A model for sustainability. Agron. J. 100:1013-1019.

Causarano, H.J., A.J. Franzluebbers, D.W. Reeves, and J.N. Shaw. 2006. Soil organic carbon sequestration in cotton production systems of the southeastern United States: A review. J. Environ. Qual. 35:1374-1383.

CCSP. 2008. The effects of climate change on agriculture, land resources, water resources, and biodiversity. A Report by the U.S. Climate Change Science Program and the Subcommittee on Global Change Research. P. Backlund, A. Janetos, D. Schimel, J. Hatfield, K. Boote, P. Fay, L. Hahn, C. Izaurralde, B.A. Kimball, T. Mader, J. Morgan, D. Ort, W. Polley, A. Thomson, D. Wolfe, M. Ryan, S. Archer, R. Birdsey, C. Dahm, L. Heath, J. Hicke, D. Hollinger, T. Huxman, G. Okin, R. Oren, J. Randerson, W. Schlesinger, D. Lettenmaier, D. Major, L. Poff, S. Running, L. Hansen, D. Inouye, B.P. Kelly, L Meyerson, B. Peterson, R. Shaw. USEPA, Washington, DC.

Chen, R.S. 1990. Global agriculture, environment, and hunger: Past, present and future links. Environ. Impact Assess. Rev. 10(4):335-358.

Chichester, F.W., and C.W. Richardson. 1992. Sentiment and nutrient loss from clay soils as affected by tillage. J. Environ. Qual. 21:587-590.

Christopher, S.F., R. Lal, and U. Mishra. 2009. Regional study on no-till effects on carbon sequestration in the Midwestern United States. Soil Sci. Soc. Am. J. 73:207-216.

Cleveland, C.J. 1995. Resource degradation, technical change, and productivity of energy use in U.S. agriculture. Ecol. Econ. (Amsterdam) 13:185-201.

Collins, H.P., P.E. Rasmussen, and C.L. Douglas. 1992 Crop rotation and residue management effects on soil carbon and microbial dynamics. Soil Sci. Soc. Am. J. 56:783-788.

Cornish, P.S., and J.E. Pratley (ed.) 1987. Tillage: New direction in Australian agriculture. Inkata Press, Sydney, Australia.

Crutzen, P.J., A.R. Mosier, K.A. Smith, and W. Winiwarter 2007. $\mathrm{N}_{2} \mathrm{O}$ release from agro-biofuel production negates global warming reduction by replacing fossil fuels. Atmos. Chem. Phys. Discuss. 7:1-15.

Dabney, S.M., J.A. Delgado, and D.W. Reeves. 2001. Using winter cover crops to improve soil and water quality. Commun. Soil Sci. Plant Anal. 32:1221-1250.

Dalal, R.C., W.M. Strong, E.J. Weston, J.E. Cooper, K.J. Lehane, A.J. King, and C.J. Chicken. 1995. Sustaining productivity of a Vertisol at Warra, Queensland with fertilisers, no-tillage, or legumes. 1. Organic matter status. Aust. J. Exp. Agric. 35:903-913.
Deen, W., and P.K. Kataki. 2003. Carbon sequestration in a long-term conventional versus conservation tillage experiment. Soil Tillage Res. 74:143-150.

Derpsch, R. 2001. Frontiers in conservation tillage and advances in conservation practice. p. 248-254. In D.E. Stout et al. (ed.) Sustaining the global farm. International Soil Conservation Organization in cooperation with the USDA and Purdue University, West Lafayette, IN.

Dick, W.A., and J.T. Durkalski. 1997. No-tillage production agriculture and carbon sequestration in a Typic Fragiudalf soil of northeastern Ohio. p. 59-71. In R Lal et al. (ed.) Management of carbon sequestration in soil. CRC Press, Boca Raton, FL.

Doran, J.W. 1980. Microbial changes associated with residue management with reduced tillage. Soil Sci. Soc. Am. J. 44:518-524.

Doran, J.W. 1987. Microbial biomass and mineralizable nitrogen distributions in no-tillage and plowed soils. Biol. Fertil. Soils 5:68-75.

Doran, J.W. 2002. Soil health and global sustainability: Translating science into practice. Agric. Ecosyst. Environ. 88:119-127.

Doran, J.W., E.T. Elliott, and K. Paustian. 1998. Soil microbial activity, nitrogen cycling, and long-term changes in organic carbon pools as related to fallow tillage management. Soil Tillage Res. 49:3-18.

Doran, J.W., D.G. Fraser, M.N. Culik, and W.C. Leibhardt. 1987. Influence of alternative and conventional agricultural management on soil microbial processes and N availability. Am. J. Alternative Agric. 2:99-106.

Drinkwater, L.E., P. Wagoner, and M. Sarrantonio. 1998. Legume-based cropping systems have reduced carbon and nitrogen losses. Nature 396:262-265.

Du Pisani, J.A. 2006. Sustainable development-historical roots of the concept. J. Integrative Environ. Sci. 3(2):83-96.

Ehrlich, P.R., A.H. Ehrlich, and G.C. Daily. 1993. Food security, population, and the environment. Popul. Dev. Rev. 19:1-32.

Ellert, B.H., and H.H. Janzen. 1999. Short-term influence of tillage on $\mathrm{CO}_{2}$ fluxes from a semi-arid soil on the Canadian Prairies. Soil Tillage Res. 50:21-32.

Eswaran, H., P.F. Reich, and F.H. Beinroth. 1997. Global distribution of soils with acidity. p. 159-164. In A.Z Moniz et al. (ed.) Plant-Soil Interactions at Low $\mathrm{pH}$ : Sustainable Agriculture and Forestry Production. Proc. of the 4th International Symp. on Plant-Soil Interactions at Low $\mathrm{pH}$, Belo Horizonte, Minas Gerais, Brazil. 17-24 Mar. 1996.

FAO. 2009. Conservation agriculture. Available at http:// www.fao.org/ag/ca/ (verified 25 Aug. 2010).

FAOSTAT. 2009. FAOSTAT online statistical service. Available at http://faostat.fao.org/default.aspx (verified 25 Aug. 2010).

Fischer, G., and G.K. Heilig. 1998. Population momentum and the demand on land and water resources. p. 8-29. In D.J. Greenland et al. (ed.) Land resources: On the edge of the Malthusian precipice? CAB International, New York.

Follett, R.F., J.Z. Castellanos, and E.D. Buenger. 2005. Carbon dynamics and sequestration in an irrigated Vertisol in Central Mexico. Soil Tillage Res. 83:148-158.

Garcia, JP, C.S. Wortmann, M. Mamo, R. Drijber, and D. Tarkalson. 2007. One-time tillage of no-till: Effects on nutrients, mycorrhizae, and phosphorus uptake. Agron. J. 99:1093-1103.

Gardner, G. 1996. Shrinking fields: Cropland lost in a world of 8 billion. World Watch Institute, Washington, DC.

Garten, C.T., and S.D. Wullschleger. 1999. Soil carbon inventories under a bioenergy crop (switchgrass): Measurement limitations. J. Environ. Qual. 28:1359-1365.

Gebregziabher, S., M.M. Mouaen, H. Van Brussel, H. Ramon, J. Nyssen, H. Verplancke, M. Behailu, J. Deckers, and J. De Baerdemaeker. 2006. Animal drawn 
tillage: The Ethiopian ard plough, maresha: A review. Soil Tillage Res. 89:129-143.

Giampietro, M., S. Ulgiati, and D. Pimentel. 1997. Feasibility of large-scale biofuel production. Bioscience 47(9):587-600.

Gilley, J.E., and J.W. Doran. 1997. Tillage effects on soil erosion potential and soil quality of a former conservation reserve program site. J. Soil Water Conserv. 52:184-188.

Gollany, H.T., T.E. Schumacher, P.D. Evenson, M.J. Lindstrom, and G.D. Lemme. 1991. Aggregate stability of an eroded and desurfaced Typic Argiustoll. Soil Sci. Soc. Am. J. 55:811-816.

Gollany, H.T., T.E. Schumacher, M.J. Lindstrom, P. Evenson, and G.D. Lemme. 1992. Topsoil thickness and desurfacing effects on properties and productivity of a typic Argiustoll. Soil Sci. Soc. Am. J. 56:220-225.

Govers, G., K. Vandaele, P.J. Desmet, J. Poesen, and K. Bunte. 1994. The role of tillage in soil redistribution on hillslopes. Eur. J. Soil Sci. 45:469-478.

Graham, R.L., R. Nelson, J. Sheehan, R.D. Perlack, and L.L. Wright. 2007. Current and potential U.S. corn stover supplies. Agron. J. 99:1-11.

Grandy, A.S., G.A. Porter, and M. Erich. 2002. Organic amendment and rotation crop effects on the recovery of soil organic matter and aggregation in potato cropping systems. Soil Sci. Soc. Am. J. 66:1311-1319.

Grandy, A.S., G.P. Robertson, and K.D. Thelen. 2006. Do productivity and environmental trade-offs justify periodically cultivating no-till cropping systems? Agron. J. 98:1377-1383.

Greenland, D.J., P.J. Gregory, and P.H. Nye (ed.) 1998. Land resources: On the edge of the Malthusian precipice? CAB International, New York.

Greenland, D.J., and I. Szabolc (ed.) 1994. Soil resilience and sustainable land use. CAB International, Wallingford, UK.

Grigal, D.F., and W.E. Berguson. 1998. Soil carbon changes associated with short-rotation systems. Biomass Bioenergy 14:371-377.

Hatfield, J., K. Boote, P. Fay, L. Hahn, C. Izaurralde, B.A. Kimball, T. Mader, J. Morgan, D. Ort, W. Polley, A. Thomson, and D. Wolfe. 2008. Agriculture. In The effects of climate change on agriculture, land resources, water resources, and biodiversity. A Report by the U.S. Climate Change Science Program and the Subcommittee on Global Change Research Washington, DC.

Havlin, J.L., D.E. Kissel, L.D. Maddux, M.M. Classen, and J.H. Long. 1990. Crop rotation and tillage effects on soil organic carbon and nitrogen. Soil Sci. Soc. Am. J. $54: 448-452$.

Heimlich, R.E., and W.D. Anderson. 2001. Development at the urban fringe and beyond: Impacts on agriculture and rural land. Agric. Econ. Rep. 803. USDA-ERS, Washington, DC.

Heimsath, A.M., W.E. Dietrich, K. Nishiizumi, and R.C. Finkel. 1999. Cosmogenic nuclides, topography, and the spatial variation of soil depth. Geomorphology 27(1-2):151-172.

Helvey, J.D., A.R. Tiedmann, and T.D. Anderson. 1985. Plant nutrient losses by soil erosion and mass movement after wildfire. J. Soil Water Conserv. 40:168-173.

Hooker, B.A., T.F. Morris, R. Peters, and Z.G. Cardon. 2005. Long-term effects of tillage and corn stalk return on soil carbon dynamics. Soil Sci. Soc. Am. J. 69:188-196.

Hoskinson, R.L., D.L. Karlen, S.J. Birrell, C.W. Radtke, and W.W. Wilhelm. 2007. Engineering, nutrient removal, and feedstock conversion evaluations of four corn stover harvest scenarios. Biomass Bioenergy 31:126-136.

Huggins, D.R., R.R. Allmaras, C.E. Clapp, J.A. Lamb, and G.W. Randall. 2007. Corn-soybean sequence and tillage effects on soil carbon dynamics and storage. Soil Sci. Soc. Am. J. 71:145-154.
Huggins, D.R., and J.P. Reganold. 2008. No-till: The quiet revolution. Sci. Am. 7:70-77.

IPCC. 2007. Climate change 2007: The physical science basis, summary for policymakers. The 4th Assessment Report. Available at www.ipcc.ch (verified 25 Aug. 2010).

Ismail, I., R.L. Blevins, and W.W. Frye. 1994. Long-term no-tillage effects on soil properties and continuous corn yields. Soil Sci. Soc. Am. J. 58:193-198.

Izaurralde, R.C., N.J. Rosenberg, and R. Lal. 2001. Mitigation of climate change by soil carbon sequestration. Adv. Agron. 70:1-75.

Jackson, L.E., F.J. Calderón, K.L. Steenwerth, K.M. Scow, and D. Rolston. 2003. Responses of soil microbial processes and community structure to tillage events and implications for soil quality. Geoderma 114:305-317.

Janzen, H.H., C.A. Campbell, E.G. Gergorich, and B.H. Ellert. 1998. Soil carbon dynamics in Canadian agroecosystems. p. 57-80. In R. Lal et al. (ed.) Soil processes and the carbon cycle. CRC Press, Boca Raton, FL.

Jastrow, J.D., T.W. Boutton, and R.M. Miller. 1996. Carbon dynamics of aggregate-associated organic matter estimated by carbon-13 natural abundance. Soil Sci. Soc. Am. J. 60:801-807.

Jenkinson, D.S. 1991. The Rothamsted long-term experiments: Are they still of use? Agron. J. 83:2-10.

Johnson, J.M.F., R.R. Allmaras, and D.C. Reicosky. 2006a. estimating source carbon from crop residues, roots and rhizodeposits using the national grain-yield database. Agron. J. 98:622-636.

Johnson, J.M.-F., M.D. Coleman, R. Gesch, A. Jaradat, R. Mitchell, D. Reicosky, and W.W. Wilhelm. 2007. Biomass-bioenergy crops in the United States: A changing paradigm. The Americas. J. Plant Sci. Biotechnol. 1(1):1-28.

Johnson, J.M., D.C. Reicosky, R.R. Allmaras, D.W. Archer, and W.W. Wilhelm. 2006b. A matter of balance: Conservation and renewable energy. J. Soil Water Conserv. 61(4):120A-125A

Kanchikerimath, M., and D. Singh. 2001. Soil organic matter and biological properties after 26 years of maize-wheat-cowpea cropping as affected by manure and fertilization in a Cambisol in semiarid region of India. Agric. Ecosyst. Environ. 86:155-162.

Karlen, D.L., N.C. Wollenhaupt, D.C. Erbach, E.C. Berry, J.B. Swan, N.S. Eash, and J.L. Jordahl. 1994a. Corn residue effects on soil quality following 10 years of no-till corn. Soil Tillage Res. 31:149-167.

Karlen, D.L., N.C. Wollenhaupt, D.C. Erbach, E.C. Berry, J.B. Swan, N.S. Eash, and J.L. Jordahl. 1994b. Long-term tillage effects on soil quality. Soil Tillage Res. 32:313-327.

Kern, J.S., and M.G. Johnson. 1993. Conservation tillage impacts on national soil and atmospheric carbon levels. Soil Sci. Soc. Am. J. 57:200-210.

Khan, S.A., R.L. Mulvaney, T.R. Ellsworth, and C.W Boast. 2007. The myth of nitrogen fertilization for soil carbon sequestration. J. Environ. Qual. 36:1821-1832.

Kuo, S., and E.J. Jellum. 2002. Influence of winter cover crop and residue management on soil nitrogen availability and corn. Agron. J. 94:501-508.

Lafond, G.P., D.A. Derksen, H.A. Loeppky, and D. Struthers. 1994. An agronomic evaluation of conservation tillage systems and continuous cropping in East Central Saskatchewan. J. Soil Water Conserv. 49:387-393.

Lal, R. 1987. Effects of soil erosion on crop productivity. Crit. Rev. Plant Sci. 5(4):303-367.

Lal, R. 1989. Land degradation and its impact on food and other resources. p. 65-68. In D. Pimentel and C.W. Hall (ed.) Food and natural resources. Academic Press, San Diego, CA.

Lal, R. 1994. Sustainable land use systems and soil resilience. p. 41-68. In D.J. Greenland and I. Szaboles (ed.) Soil resilience and sustainable land use. CAB International, Wallingford, U.K. 
Lal, R. 1995. Global soil erosion by water and carbon dynamics. p. 131-140. In R. Lal et al. (ed.) Soils and global change. Lewis Publ., Boca Raton, FL.

Lal, R. 1997. Degradation and resilience of soils. Phil. Trans. R. Soc. Land. B. 352:997-1010.

Lal, R. 1998. Soil erosion impact on agronomic productivity and environmental quality. Crit. Rev. Plant Sci. 17(4):319-464.

Lal, R. 1999a. Soil management and restoration for C sequestration to mitigate the accelerated greenhouse effect. Prog. Environ. Sci. 1:307-326.

Lal, R. 1999b. Global carbon pools and fluxes and the impact of agricultural intensification and judicious land use. p. 45-52. In Prevention of land degradation, enhancement of carbon sequestration and conservation of biodiversity through land use change and sustainable land management with a focus on Latin America and the Caribbean. World Soil Resources Rep. 86. FAO, Rome.

Lal, R. 2003. Soil erosion and the global carbon budget. Environ. Int. 29(4):437-450.

Lal, R. 2004. Soil carbon sequestration impacts on global climate change and food security. Science 304:1623-1627.

Lal, R., J.M. Kimble, R.F. Follet, and V. Cole. 1998. Potential of U.S. cropland for carbon sequestration and greenhouse effect mitigation. Ann Arbor Press, Chelsea, MI

Lal, R., D.C. Reicosky, and J.D. Hanson. 2007. Evolution of the plow over 10,000 years and the rationale for no-till farming. Soil Tillage Res. 93:1-12.

Larson, W.E. 1979. Crop residues: Energy production or erosion control? J. Soil Water Conserv. 34:74-76.

Larson, W.E., C.E. Clapp, W.H. Pierre, and Y.B. Morachan. 1972. Effects of increasing amounts of organic residues on continuous corn. II. Organic carbon, nitrogen phosphorus and sulfur. Agron. J. 64:204-208.

Larson, W.E., F.J. Pierce, and R.H. Dowdy. 1983. The threat of soil erosion to long-term crop production. Science 219:458-465.

Lemus, R., and R. Lal. 2005. Bioenergy crops and carbon sequestration. Crit. Rev. Plant Sci. 24:1-21.

Liebig, M.A., J.A. Morgan, J.D. Reeder, B.H. Ellert, H.T. Gollany, and G.E. Schuman. 2005. Greenhouse gas contributions and mitigation potential of agricultura practices in northwestern USA and western Canada. Soil Tillage Res. 83:25-52.

Lindstrom, M.J., W.W. Nelson, and T.E. Schumacher. 1992 Quantifying tillage erosion rates due to moldboard plowing. Soil Tillage Res. 44:243-255.

Lindstrom, M.J., J.A Schumacher, and T.E Schumacher. 2000. TEP: A tillage erosion prediction model to calculate soil translocation rates from tillage. J. Soil Water Conserv. 55(1):105-108.

Lobb, D., E. Huffman, and D. Reicosky. 2007. Importance of information on tillage practices in the modelling of environmental processes and in the use of environmental indicators. J. Environ. Manage. 82:377-387.

Lobb, D.A., R.G. Kachanoski, and M.H. Miller. 1995. Tillage translocation and tillage erosion on shoulder slope landscape positions measured using cesium-137 as a tracer. Can. J. Soil Sci. 75:211-218.

Lowdermilk, W.C. 1953. Conquest of the land through 7000 years. Bull. 99. USDA Soil Conservation Service, Washington, DC.

Mangas, V.J., J.R. Sanchez, and C. Oritz. 1992. Effects of a fire on runoff and erosion on the Mediterranean forest soils in SE Spain. Pirineos 140:37-51.

Mann, L., V. Tolbert, and J. Cushman. 2002. Potential environmental effects of corn (Zea Mays L.) stover removal with emphasis on soil organic matter and erosion. Agric. Ecosyst. Environ. 89:149-166.

Mikha, M.M., and C.W. Rice. 2004. Tillage and manure effects on soil and aggregate-associated carbon and nitrogen. Soil Sci. Soc. Am. J. 68:809-816.
Moebius-Clune, B.N., H.M. van Es, O.J. Idowu, R.R. Schindelbeck, D.J. Moebius-Clune, D.W. Wolfe, G.S. Abawi, J.E. Thies, B.K. Gugino, and R. Lucey. 2008. Long-term effects of harvesting maize stover and tillage on soil quality. Soil Sci. Soc. Am. J. 72(4):960-969.

Montgomery, D.R. 2007. Soil erosion and agricultural sustainability. Proc. Natl. Acad. Sci. 104(33):13268-13272.

Murage, E.W., and P. Voroney. 2008. Distribution of organic carbon in the stable soil humic fractions as affected by tillage management. Can. J. Soil Sci. 88(1):99-106.

Organization for Economic Co-operation and Development. 2001. Environmental indicators for Agriculture. Vol. 3. Methods and Results. Available at http://www. oecd.org/dataoecd/24/35/40680869.pdf (verified 25 Aug. 2010). Organization for Economic Co-operation and Development, Paris, France.

Olchin, G.P., S. Ogle, S.D. Frey, T.R. Filley, K. Paustian, and J. Six. 2008. Residue carbon stabilization in soil aggregates of no-till and tillage management of dryland cropping systems. Soil Sci. Soc. Am. J. 72:507-513.

Oldeman, L.R., R.T.A. Hakkeling, and W.G. Sombroek. 1991. World map of the status of human-induced soil degradation: An explanatory note. International Soil Information and Reference Centre, Wageningen, the Netherlands.

Park, B.B., R.D. Yania, J.M. Sahm, D.K. Lee, and L.P. Abrahamson. 2005. Wood ash effects on plant and soil in a Willow bioenergy plantations. Biomass Bioenergy 28:355-365.

Paustian, K., H.P. Collins, and E.A. Paul. 1997. Management controls on soil carbon. p. 15-49. In E.A. Paul et al. (ed.) Soil organic matter in temperate agroecosystems: Long-term experiments in North America. CRC Press, Boca Raton, FL.

Peterson, J.B. 1964. The relation of soil fertility to soil erosion. J. Soil Water Conserv. 9:15-18.

Phillips, R.E., and S.H. Phillips (ed.) 1984. No-tillage agriculture, principles and practices. Van Nostrand Reinhold Co., New York.

Phillips, S.H., and H.M. Young. 1973. No-tillage farming Reiman Associates, Milwaukee, WI.

Pierce, F.C., M.-C. Fortin, and M.J. Staton. 1994. Periodic plowing effects on soil properties in a no-till farming system. Soil Sci. Soc. Am. J. 58:1782-1787.

Pimentel, D. 1993. World soil erosion and conservation. Cambridge Univ. Press, Cambridge, MA

Pimentel, D., J. Allen, A. Beers, L. Guinand, R. Linder, P. McLaughlin, B. Meer, D. Musonda, D. Perdue, S. Poisson, S. Siebert, K. Stoner, R. Salazar, and A. Hawkins. 1987. World agriculture and soil erosion. Bioscience 37:277-283

Pimentel, D., C. Harvey, P. Resosudarmo, K. Sinclair, D. Kurz, M. McNair, S. Crist, L. Sphpritz, L. Fitton, R. Saffouri, and R. Blair. 1995. Environmental and economic costs of soil erosion and conservation benefits. Science 267:1117-1123.

Plieninger, T., and O. Bens. 2007. How the emergence of biofuels challenges environmental conservation. Environ. Conserv. 34(4):273-275.

Poesen, J., B. van Wesemael, G. Govers, G.J. MartinezFernandez, P. Desmet, K. Vandaele, K.T. Quine, and G. Degraer. 1997. Patterns of rock fragment cover generated by tillage erosion. Geomorphology 18:183-197.

Postel, S. 1989. Water for agriculture: Facing the limit. Worldwatch Paper 93. Worldwatch Institute, Washington, DC.

Quincke, J.A., C.S. Wortmann, M. Mamo, T. Franti, R.A Drijber, and J.P. Garcia. 2007. One-time tillage of notill systems: Soil physical properties, phosphorus runoff, and crop yield. Agron. J. 99(4):1104-1110.

Ramankutty, N., J.A. Foley, and N.J. Olejniczak. 2002 People on the land: Changes in global population and croplands during the 20th century. Ambio 31(3):251-257. 
Rasmussen, P.E., and C.R. Rohde. 1988. Long-term tillage and nitrogen fertilization affects on organic $\mathrm{N}$ and $\mathrm{C}$ in a semi-arid soil. Soil Sci. Soc. Am. J. 44:596-600.

Reeder, R., and D. Westermann. 2007. Soil management. p. 1-87. In M. Schnepf and C. Cox (ed.) Environmental benefits of conservation on cropland. Soil Water Conserv. Soc., Ankeny, IA.

Reicosky, D.C. 1997. Tillage-induced $\mathrm{CO}_{2}$ emission from soil. Nutr. Cycl. Agroecosyst. 49:273-285.

Reicosky, D.C. 2001a. Conservation agriculture: Global environmental benefits of soil carbon management. $p$ 3-12. In L. Garcia-Torres et al. (ed.) Conservation agriculture: A worldwide challenge. XUL, Cordoba, Spain.

Reicosky, D.C. 2001b. Tillage-induced $\mathrm{CO}_{2}$ emissions and carbon sequestration: Effect of secondary tillage and compaction. p. 265-274. In L. Garcia-Torres et al. (ed.) Conservation agriculture: A worldwide challenge. XUL, Cordoba, Spain.

Reicosky, D.C. 2002. Long-term effect of moldboard plowing on tillage-induced $\mathrm{CO}_{2}$ loss. p. 87-97. In J.M Kimble and R. Lal (ed.) Agricultural practices and policies for carbon sequestration in soil. CRC Press, Boca Raton, FL.

Reicosky, D.C. 2008. Carbon sequestration and environmental benefits from no-till systems. p. 43-58. In $\mathrm{T}$. Goddard et al. (ed.) No-till farming systems. Spec. Publ. 3. World Assoc. Soil and Water Conserv., Bangkok, Thailand.

Reicosky, D.C., and R.R. Allmaras. 2003. Advances in tillage research in North American cropping systems. p. 75-125. In A. Shrestha (ed.) Cropping systems: Trends and advances. Haworth Press, New York.

Reicosky, D.C., S.D. Evans, C.A. Cambardella, R.R. Allmaras, A.R. Wilts, and D.R. Huggins. 2002. Continuous corn with moldboard tillage: Residue and fertility effects on soil carbon. J. Soil Water Conserv. 57:277-284

Reicosky, D.C., R.W. Gesch, S.W. Wagner, R.A. Gilbert, C.D. Wente, and D.R. Morris. 2008. Tillage and wind effects on soil $\mathrm{CO}_{2}$ concentrations in muck soils. Soil Tillage Res. 99:221-231.

Reicosky, D.C., J.L. Hatfield, and R.L. Sass. 2000. Agricultural contributions to greenhouse gas emissions. p. 37-55. In K.R. Reddy and H.F. Hodges (ed.) Climate change and global crop productivity. CABI Publishing, Wallingford, UK.

Reicosky, D.C., W.D. Kemper, G.W. Langdale, C.W. Douglas, Jr., and P.E. Rasmussen. 1995. Soil organic matter changes resulting from tillage and biomass production. J. Soil Water Conserv. 50:253-261.

Reicosky, D.C., and M.J. Lindstrom. 1993. Fall tillage method: Effect on short-term carbon dioxide flux from soil. Agron. J. 85:1237-1243.

Reicosky, D.C., and M.J. Lindstrom. 1995. The impact of fall tillage on short-term carbon dioxide flux. p. 177187. In R. Lal et al. (ed.) Soils and global change. Lewis Publ., Chelsea, MI.

Reicosky, D.C., and K.E. Saxton. 2007a. The benefits of no-tillage. p. 11-20. In C.J. Baker et al. (ed.) No-tillage seeding in conservation agriculture. FAO and CAB International, Rome, Italy.

Reicosky, D.C., and K.E. Saxton. 2007b. Reduced environmental emissions and carbon sequestration. p. 257-267. In C.J. Baker et al. (ed.) No-tillage seeding in conservation agriculture. FAO and CAB International, Rome, Italy.

Robertson, G.P., E. Paul, and R.R. Harwood. 2000. Greenhouse gases in intensive agriculture: Contribution of individual gasses to the radiative forcing of the atmosphere. Science 289:1922-1925.

Robertson, G.P., and S.M. Swinton. 2005. Reconciling agricultural productivity and environmental integrity: A grand challenge for agriculture. Front. Ecol. Environ. 3(1):38-46.

Rochette, P., and E.G. Gregorich. 1998. Dynamics of soil microbial biomass $\mathrm{C}$, soluble organic $\mathrm{C}$, and $\mathrm{CO}_{2}$ evo- lution after three years of manure application. Can. J. Soil Sci. 78:283-290.

Rosenzweig, C., and D. Hillel. 1995. Potential impacts of climate change on agriculture and food supply. Consequences 1(2). Available at http://www.gcrio.org/ CONSEQUENCES/summer95/agriculture.html (verified 25 Aug. 2010).

Rosenzweig, C., M.L. Parry, G. Fischer, and K. Frohberg. 1993. Climate change and world food supply. Research Rep. 3. Oxford University, Oxford.

Russell, A.E., D.A. Laird, and A.P. Mallarino. 2006 Nitrogen fertilization and cropping system impacts on soil quality in Midwestern Mollisols. Soil Sci. Soc. Am. J. 70:249-255.

Sa, J.C.M., C.C. Cerri, W.A. Dick, R. Lal, S.P. Venske Fishlo, M.C. Piccolo, and B.E. Feil. 2001. Organic matter dynamics and carbon sequestration rates for a tillage chronosequence in a Brazilian oxisoil. Soil Sci. Soc. Am. J. 65:1486-1499.

Sanchez, J.E., R.R. Harwood, T.C. Willson, K. Kizilkaya, J. Smeenk, E. Parker, E.A. Paul, B.D. Knezek, and G.P. Robertson. 2004. Managing soil carbon and nitrogen for productivity and environmental quality. Agron. J. 96:769-775.

Sandor, J.A., and N.S. Eash. 1995. Ancient agricultural soils in the Andes of Southern Peru. Soil Sci. Soc. Am. J. 59:170-179.

Schumacher, T.E., M.J. Lindstrom, J.A. Schumacher, and G.D. Lemme. 1999. Modeling spatial variation and productivity due to tillage and water erosion. Soil Tillage Res. 51(3-4):331-339.

Shaver, T.M., G.A. Peterson, and L.A. Sherrod. 2003. Cropping intensification in dryland systems improves soil physical properties: Regression relations. Geoderma 116:149-164.

Shepherd, T.G., S. Saggar, R.H. Newman, C.W. Ross, and J.L. Dando. 2001. Tillage-induced changes to soil structure and organic carbon fractions in New Zealand soils. Aust. J. Soil Res. 39(3):465-467.

Six, J., E.T. Elliott, K. Paustian, and J.W. Doran. 1998. Aggregation and soil organic matter accumulation in cultivated and native grassland soils. Soil Sci. Soc. Am. J. 62:1367-1377.

Six, J., C. Feller, K. Denef, S.M. Ogle, and J.C.M. Sa. 2002. Soil organic matter, biota and aggregation in temperate and tropical soils-Effects of no-tillage. Agronomie (Paris) 22:755-775.

Six, J., S.M. Ogle, F.J. Breidt, R.T. Conant, A.R. Mosier, and K. Paustian. 2004. The potential to mitigate global warming with no-tillage management is only realized when practiced in the long-term. Glob. Change Biol. 10(2):155-160.

Smil, V. 1987. Energy, food, environment: Realities, myths, options. Oxford Univ. Press, New York.

Smith, P., C.M. Fang, J.J.C. Dawson, and J.B. Moncrieff. 2008. Impact of global warming on soil organic carbon. Adv. Agron. 97:1-43.

Smith, P., and D.S. Powlson. 2000. Considering manure and carbon sequestration. Science 287:428-429.

Smith, P., D.S. Powlson, M.J. Glendining, and J.U. Smith. 1998. Preliminary estimates of the potential for carbon mitigation in European soils through no-till farming. Glob. Change Biol. 4:679-685.

Smith, S.V., W.H. Renwick, R.W. Buddemeier, and C.J. Crossland. 2001. Budgets of soil erosion and deposition for sediments and sedimentary organic carbon across the conterminous United States. Global Biogeochem. Cycles 15:697-707.

Stockfisch, N., T. Forstreuter, and W. Ehlers. 1999. Ploughing effects on soil organic matter after 20 years of conservation tillage in Lower Saxony, Germany. Soil Tillage Res. 52:91-101.

Tiessen, H., and J.W.B. Stewart. 1983. Particle size fractions and their use in studies of soil organic matter: II. 
Cultivation effects on organic matter composition in size fractions. Soil Sci. Soc. Am. J. 47:509-514.

Tinker, P.B. 1998. The environmental implications of intensified land use in developing countries. p. 163 173. In D.J. Greenland et al. (ed.) Land resources: On the edge of the Malthusian precipice? CAB International, New York.

Tisdall, J.M. 1996. Formation of soil aggregates and accumulation of soil organic matter. p. 57-96. In M.R. Carter and B.A. Stewart (ed.) Structure and organic matter storage in agricultural soils. CRC/Lewis Publ., Boca Raton, FL.

Tisdall, J.M., and J.M. Oades. 1982. Organic matter and water-stable aggregates in soils. J. Soil Sci. 33:141-163.

Titi, A.E. (ed.) 2003. Soil tillage in agroecosystems. CRC Press, New York.

Tracy, P.W., D.G. Westfall, E.T. Elliott, G.A. Peterson, and C.V. Cole. 1990. Carbon, nitrogen, phosphorus and sulfur mineralization in plow and no-till cultivation. Soil Sci. Soc. Am. J. 54:457-461.

Troeh, F.R., J.A. Hobbs, and R.L. Donahue. 1999. Soil and water conservation: Productivity and environmental protection. 3rd ed. Am. Acad. of Environ. Eng. Annapolis, MD.

Uhlen, G., and S. Tveitnes. 1995. Effects of long-term crop rotation, fertilizers, farm manure and straw on soil productivity. Norwegian J. Agric. Sci. 9:143-161.

U.S. Census Bureau. 2007. Total midyear population for the world: 1950-2050. Available at http://www.census. gov/ipc/www/worldpop.html (verified 25 Aug. 2010.)

VandenBygaart, A.J., and B. Kay. 2004. Persistence of soil organic carbon after plowing a long-term no till field in southern Ontario, Canada. Soil Sci. Soc. Am. J. 68:1394-1402.

Volk, T.A., T. Verwijst, P.J. Tharakan, L.P. Abrahamson, and E.H. White. 2004. Growing fuel: A sustainability assessment of Willow biomass crops. Front. Ecol. Environ. 2:411-418.

Wallingford, G.W. 1991. The U.S. nutrient budget in the red. Better Crops Plant Food 75:16-18.

Wanniarachchi, S.D., R.P. Voroney, T.J. Vyn, R.P. Beyaert, and A.F. MacKenzie. 1999. Tillage effects on the dynamics of total and corn-residue derived soil organic matter in two southern Ontario soils. Can. J. Soil Sci. 79:473-480.

Warkentin, B.P. 2001. The tillage effect in sustaining soil functions. J. Plant Nutr. Soil Sci. 164(4):345-350.

Warkentin, B.P. 2008. Soil structure: A history from tilth to habitat. Adv. Agron. 97:239-272.

Weast, R.C. 1968. CRC handbook of chemistry and physics. 48th ed. F-135. Chemical Rubber Co., Boca Raton, FL.

Weast, R.C. 1981. CRC handbook of chemistry and physics. 61st ed. F-202. Chemical Rubber Co., Boca Raton, FL

Webster, C.P., and K.W.T. Goulding. 1989. Influence of soil carbon content on denitrification from fallow land during autumn. J. Sci. Food Agric. 49:131-142.

West, T.O., and W.M. Post. 2002. Soil organic carbon sequestration rates by tillage and crop rotation: A global data analysis. Soil Sci. Soc. Am. J. 66:1930-1946.

Wiebe, K. 2003. Linking land quality, agricultural productivity, and food security. Agric. Econ. Rep. 823. Resource and Economics Division, USDA-ERS, Washington, DC.

Wilhelm, W.W., J.M.-F. Johnson, J.L. Hatfield, W.B. Voorhees, and D.R. Linden. 2004. Crop and soil productivity response to corn residue removal: A literature review. Agron. J. 96:1-17.

Wilhelm, W.W., J.M.F. Johnson, D.L. Karlen, and D.T. Lightle. 2007. Corn stover to sustain soil organic carbon further constrains biomass supply. Agron. J. 99:1665-1667.

Wilts, A.R., D.C. Reicosky, R.R. Allmaras, and C.E. Clapp. 2004. Long-term corn residue effects: Harvest alternatives, soil carbon turnover, and root-derived carbon. Soil Sci. Soc. Am. J. 68:1342-1351.

Wolf, J., P.S. Bindraban, J.C. Luijten, and L.M. Vleeshouwers. 2003. Exploratory study on the land area required for global food supply and the potential global production of bioenergy. Agric. Syst. 76:841-861

Young, A. 1999. Is there really spare land? A critique of estimates of available cultivable land in developing countries. Environ. Dev. Sustain. 1:3-18. 
